\title{
HUKUM PERJANJIAN (DALAM PERSPEKTIF PERJANJIAN KARYA PENGUSAHAAN PERTAMBANGAN BATUBARA)
}

\author{
Hartana \\ Direktur Utama PT. Bumi Kencana Eka Sejahtera \\ Kandidat Doktor Fakultas Hukum Universitas Gadjah Mada Yogyakarta \\ Email : hartana_palm@yahoo.com
}

\begin{abstract}
ABSTRAK
Konsensualitas merupakan prinsip atau asas fundamental dalam hukum perjanjian dimana suatu persetujuan dapat terjadi karena persesuaian kehendak (konsensus) para pihak. Pada umumnya suatu persetujuan dapat dibuat "bebas bentuk" dan tidak formal atau perjanjian sudah terjadi dan bersifat mengikat sejak tercapai kesepakatan (konsensus) antara kedua belah pihak mengenai suatu obyek perjanjian.

Pasal 33 Ayat (3) Undang-Undang Dasar 1945 merumuskan bahwa "Bumi dan air dan kekayaan alam yang terkandung di dalamnya dikuasai oleh negara dan dipergunakan untuk sebesar-besarnya kemakmuran rakyat".

Berdasar ketentuan tersebut, mineral dan batubara yang merupakan sumber daya alam dikuasai oleh negara dan pengelolaannya harus memberi nilai tambah bagi perekonomian nasional guna mencapai kemakmuran dan kesejahteraan rakyat. Untuk mencapai tujuan tersebut maka pengelolaan pertambangan mineral dan batubara oleh Negara harus berazaskan manfaat, keadilan dan keseimbangan serta keberpihakan kepada kepentingan bangsa sesuai ketentuan Undang-Undang No. 4 Tahun 2009 tentang Pertambangan Mineral dan Batubara. Pemerintah selaku aparatur negara mengatur dan menentukan penyelenggaraan, perubahan, penggunaan, persediaan dan pemeliharaan cadangan batubara serta menentukan dan mengatur hubungan hukum mengenai pertambangan batubara serta hubungan hukum antara orang-orang dengan sumber daya batubara.

Secara yuridis, hubungan hukum sebagaimana dimaksud di atas dapat dituangkan dalam suatu bentuk perjanjian yang merupakan konsensus para pihak, yaitu Perjanjian Karya Pengusahaan Pertambangan Batubara ("PKP2B") dan Kontrak Karya ("KK"). Kedua bentuk perjanjian ini telah ada pada saat diundangkannya UU No. 4 Tahun 2009 dan tetap berlaku sampai dengan masa berakhirnya kontrak/perjanjian tersebut sebagaimana ketentuan tentang peralihan pada UU No. 4 Tahun 2009 dan wajib melakukan penyesuaian selambatlambatnya 1 (satu) tahun sejak UU No. 4 Tahun 2009 tersebut diundangkan.
\end{abstract}

\section{Kata kunci : Hukum Perjanjian, Pertambangan, Perjanjian Karya Pengusahaan Pertambangan Batubara}

\section{ABSTRACT}

Konsensualitas a principle or fundamental principle in contract law where an agreement may occur because of a rapprochement will (consensus) of the parties. In general, an agreement can be made "free form" and not formal or agreement has occurred and is binding since reached an agreement (consensus) between the two 
sides regarding a particular object of the agreement. Article 33 Paragraph (3) of the Constitution of 1945.

Based on these provisions, mineral and coal are natural resources controlled by the state and its administration must provide added value to the national economy in order to achieve prosperity and welfare. To achieve these objectives, the management of mineral and coal by the State should be based on the principle of benefit, justice and balance as well as siding with the interests of the nation according to the provisions of Law No. 4 Year 2009 on Mineral and Coal Mining. Government as the state apparatus govern the implementation, change, use, supply and maintenance of coal reserves as well as to determine and regulate the legal relations concerning coal mining as well as the legal relationship between those with coal resources.

Legally, the legal relationship as referred to above can be contained in a form which is the consensus agreement of the parties, namely the Work Agreement for Coal Mining ("PKP2B") and a Contract of Work ("COW"). Both forms of this agreement have been there at the time of the enactment of Law No. 4 of 2009 and remain valid until the expiration of the contract / agreement on the transitional provisions such as the Law No. 4 of 2009 and shall make adjustments no later than 1 (one) year since the Act No. 4 of 2009 was enacted.

\section{Keywords: Contract Law, Mining, Coal Mining Agreement}

\section{Latar Belakang}

Manusia dalam kehidupannya selaku makhluk sosial selalu berhubungan dan berinteraksi antar manusia lainnya dengan meliputi beberapa aspek, diantaranya aspek sosial, budaya dan hukum, termasuk perdata. Dalam makalah ini, pembahasan lebih diarahkan pada aspek hukum perdata, khususnya hukum perjanjian tentang pengusahaan pertambangan batubara. Berbicara tentang pertambangan khususnya tambang batubara tentu tidak lepas dari masalah bisnis, dimana pada saat ini bisnis yang dilakukan manusia adalah selalu berkembang dan diharapkan selalu terus berkembang mengikuti perkembangan zaman. Sehingga perlu dipertanyakan bagaimana suatu hubungan usaha atau bisnis antar manusia dituangkan ke dalam sebuah perjanjian yang bisa mengakomodir segala kepentingan mereka termasuk adanya batasan-batasan sebagai pagar yang melindungi kepentingan para pihak apabila terjadi sesuatu hal yang tidak diinginkan, diantaranya perselisihan tentang adanya itikad baik, wanprestasi yang kesemuanya berujung pada timbulnya sengketa. Terutama dalam hal ini adalah perjanjian pertambangan batubara yang mempunyai sifat dan karakteristik perjanjian yang kompleks.

Sebelumnya perlu dipahami terlebih dahulu pengertian dari Hukum, yaitu peraturan-peraturan yang teratur, tersusun baik dan bersifat mengikat masyarakat serta bertujuan untuk menciptakan tatanan masyarakat yang tertib, damai dan adil dengan ditunjang adanya kepastian hukum sehingga kepentingan individu dan masyarakat dapat terlindungi sebagaimana tujuan normatif dari suatu negara adalah untuk mewujudkan situasi negara yang kondusif. Indonesia merupakan negara hukum dimana setiap tata 
cara pelaksanaan kehidupan didalamnya berlandaskan hukum, baik tertulis maupun tidak tertulis/abstrak yang dalam pelaksanaannya dijalankan secara bersama oleh pemerintah dan rakyat. Sementara pengertian perjanjian adalah implementasi dari poin-poin hubungan usaha atau bisnis antar manusia yang dituangkan secara tertulis dalam lembar perjanjian dan telah memiliki kesepakatan para pihak. Perjanjian memiliki hubungan erat dengan perikatan sebagaimana Buku III KUHPerdata Pasal 1233 yang menyebutkan tentang terjadinya perikatan yang mengemukakan bahwa perikatan timbul dari persetujuan atau undang-undang ( $R$. Setiawan, 1994).

Menurut Subekti, perjanjian merupakan bentuk konkrit dari perikatan sedangkan perikatan merupakan bentuk abstrak dari perjanjian, hal ini dapat diartikan adanya hubungan hukum antara dua pihak yang isinya adalah hak dan kewajiban, suatu hak untuk menuntut sesuatu dan sebaliknya suatu kewajiban untuk memenuhi tuntutan tersebut (R. Subekti, 1992).

Pengaturan tentang perikatan secara khusus terdapat dalam KUHPerdata Buku II bagian umum dari Bab I sampai dengan Bab IV, misalnya tentang bagaimana lahirnya dan hapusnya perikatan, macammacam perikatan dan sebagainya (Kitab Undang-undang Hukum Perdata).

Pasal 1313 Bab II Buku III KUHPerdata memberikan pengertian tentang perjanjian: "Suatu perbuatan dengan mana satu orang atau lebih mengikatkan dirinya terhadap satu orang lain atau lebih". Perjanjian juga adalah satu peristiwa dimana seseorang berjanji kepada orang lain atau keduanya berjanji untuk melaksanakan sesuatu hal, merupakan terjemahan dari bahasa Belanda yaitu "overeenskomst" (J. Satrio, 2001). Para pihak dalam perjanjian yang akan diadakan dan telah sepakat tentang apa yang mereka sepakati berupa janji-janji yang di perjanjikan dengan sesuatu hal yang harus dilaksanakan dinamakan 'prestasi', dapat berupa menyerahkan suatu barang, melakukan suatu perbuatan dan tidak melakukan suatu perbuatan.

Adapun perjanjian tersebut merupakan suatu Undang-undang bagi mereka yang membuatnya, dalam artian para pihak telah terikat sehingga harus tunduk serta wajib bertindak dan bersikap sesuai dengan perjanjian tersebut. Perikatan yang lahir dari perjanjian sebagaimana KUHPerdata Buku III, pasal 1338 terdapat ketentuan tentang azas "kebebasan berkontrak" (pacta sunt servanda) yaitu dalam membuat suatu perjanjian adalah bebas dalam menterjemahkan poin-poin kesepakatan asalkan tidak melanggar ketentuan, tidak melanggar ketentuan undang-undang dan tidak melanggar ketertiban umum dan kesusilaan sebagaimana Pasal 1337 KUH Perdata (J. Satrio), sehingga dapat diterjemahkan bahwa: "Semua perjanjian yang telah dibuat secara sah mengikat para pihak sebagai Undang-undang" (Kitab Undangundang Hukum Perdata), dan secara hukum sehingga jika perjanjian telah timbul, para pihak yang terikat didalamnya dituntut untuk 
melaksanakannya dengan baik layaknya undang-undang bagi mereka (Kitab Undang-undang Hukum Perdata) :

1. Perjanjian yang dibuat oleh para pihak secara sah berlaku sebagai undang-undang bagi mereka yang membuatnya.

2. Perjanjian yang telah dibuat tidak dapat ditarik kembali kecuali adanya kesepakatan dari para pihak atau karena adanya alasan yang dibenarkan oleh undang-undang.

3. Perjanjian harus dilaksanakan dengan itikad baik.

Menurut KUHPerdata, bila salah satu pihak tidak menjalankan pelaksanaan perjanjian dan tidak memenuhi kewajiban sebagaimana tertuang dalam perjanjian ataupun telah memenuhi kewajibannya namun tidak sebagaimana yang ditentukan, maka perbuatannya tersebut dikategorikan sebagai wanprestasi.

Terjadinya

prestasi, wanprestasi dan keadaan memaksa dikarenakan adanya hukum perikatan yang menurut Buku III KUHPerdata menyebutkan bahwa suatu hubungan hukum (kekayaan harta benda) terjadi antara dua orang yang memberi hak pada yang satu untuk menuntut sesuatu dari yang lainnya, sedangkan orang lainnya diwajibkan untuk memenuhi tuntutan tersebut, hal ini sebagaimana definisi dari Subekti (1980). Oleh karena sifat hukum yang termuat dalam Buku III KUHPerdata selalu berupa tuntut-menuntut maka Buku III KUHPerdata juga dinamakan perhutangan, (Sri Soedewi Masjhoen Sofran, 1987) dimana dalam implementasinya menganut 3 (tiga) asas hukum, yaitu :

1. Asas Hukum Terbuka, hukum perjanjian memberikan

kebebasan kepada masyarakat untuk mengadakan perjanjian yang berisi apa saja sepanjang tidak melanggar ketertiban umum dan kesusilaan. Mengandung suatu pengertian bahwa perjanjian-perjanjian khusus yang diatur dalam undang-undang hanyalah perjanjian-perjanjian yang telah dikenal umum di dalam masyarakat pada waktu KUHPerdata dibentuk.

2. Asas Konsensualitas, asas ini menyatakan bahwa perjanjian sudah terjadi dan bersifat mengikat sejak tercapai kesepakatan (konsensus) antara kedua belah pihak mengenai obyek perjanjian. Dapat ditetapkan apa yang menjadi hak dan kewajiban dari masingmasing pihak, sebagai contoh adalah transaksi jual beli. Perjanjian telah timbul sejak penjual melakukan penawaran atas suatu barang dan penawaran itu kemudian disetujui oleh pembeli.

3. Asas Hukum Pelengkap, beberapa pasal dalam Hukum Perjanjian dikatakan sebagai hukum pelengkap, karena pasalpasal ini melengkapi perjanjianperjanjian yang dibuat secara tidak lengkap. Biasanya orang yang mengadakan suatu perjanjian tidak mengatur secara terperinci semua persoalan yang berkaitan dengan perjanjian itu. 
UUD 1945 Pasal 33 Ayat (3) menyebutkan bahwa "Bumi dan air dan kekayaan alam yang terkandung di dalamnya dikuasai oleh negara dan dipergunakan untuk sebesar-besarnya kemakmuran rakyat" (Undangundang Dasar 1945, Pasal 33 ayat 3) Perumusan pasal ini berbeda dengan pemahaman negara lain tentang prinsip kepemilikan sumber daya alam berupa kekayaan alam yang terkandung di dalamnya yang menganut pemahaman bahwa pemilik dari tambang yang ditemukan dalam wilayah area tambang dari seseorang adalah dimiliki oleh orang tersebut. Indonesia merupakan negara yang kaya akan bahan galian (tambang) meliputi emas, perak, tembaga, minyak, gas bumi, batubara dan lainlain dimana bahan galian tersebut dikuasai oleh negara.

Peran negara dalam hal ini adalah pemerintah, wajib melaksanakan optimalisasi dan pemanfaatan potensi sumber daya alamnya secara berkelanjutan serta seoptimal mungkin bagi kepentingan rakyat dengan mempertimbangkan aspek ekonomi, sosial dan lingkungan.

Sementara pengertian hak menguasai oleh Negara sebagaimana terdapat dalam UU No. 5 Tahun 1960 tentang Peraturan Dasar Agraria ("UUPA") (UU No. 5 Tahun 1960, Peraturan Dasar Agraria ("UUPA")

1. Mengatur dan menyelenggarakan perubahan, penggunaan, persediaan dan pemeliharaan bumi, air dan ruang angkasa tersebut.

2. Menentukan dan mengatur hubungan-hubungan hukum antara orang-orang dengan bumi, air dan ruang angkasa.

3. Menentukan dan mengatur hubungan-hubungan hukum mengenai bumi, air dan ruang angkasa.

Berdasar ketentuan tersebut, batubara sebagai salah satu sumber daya alam yang terkandung dalam bumi Negara Republik Indonesia, negara berwenang atas penguasaannya untuk sebesarbesarnya kemakmuran rakyat dan Pemerintah selaku aparatur negara mengatur dan menentukan penyelenggaraan perubahan, penggunaan, persediaan dan pemeliharaan cadangan batubara, serta menentukan dan mengatur hubungan-hubungan hukum mengenai pertambangan batubara serta hubungan hukum antara orangorang dengan sumber daya batubara. Bentuk penguasaan negara atas batubara lebih lanjut dituangkan dalam peraturan perundangundangan di bidang pertambangan.

UU No. 11 Tahun 1967 tentang Ketentuan-ketentuan Pokok Pertambangan adalah peraturan perundangan di bidang pertambangan sebagai pelaksana amanat ketentuan Pasal 33 ayat (3) UUD 1945 yang telah diundangkan selama lebih kurang empat dasawarsa, walaupun dalam praktik cukup menuai berbagai permasalahan, telah memberikan sumbangan yang penting bagi pembangunan nasional. Dalam perkembangan lebih lanjut, undangundang tersebut yang materi muatannya bersifat sentralistik sudah tidak sesuai lagi dengan perkembangan situasi sekarang dan 
tantangan di masa depan. Di samping itu, pembangunan pertambangan harus menyesuaikan diri dengan perubahan lingkungan strategis, baik bersifat nasional maupun internasional. Tantangan utama yang dihadapi oleh pertambangan mineral dan batubara adalah pengaruh globalisasi yang mendorong demokratisasi, otonomi daerah, hak asasi manusia, lingkungan hidup, perkembangan teknologi dan informasi, hak atas kekayaan intelektual serta tuntutan peningkatan peran swasta dan masyarakat.

Masalah pertambangan mineral dan batubara (minerba) selama ini merupakan hal yang tak pernah selesai, mulai dari persoalan tumpang tindih, wilayah Kuasa Pertambangan sampai masalah transfer pricing (http://www.hukumonline.com).

Sektor pertambangan khususnya pertambangan batubara, mengalami masa puncak kejayaan pada era 2004 sampai dengan akhir 2006 seiring dengan melambungnya harga minyak bumi dan motivasi dari berbagai pihak untuk mencari dan memaksimalkan sumber energi selain minyak dan gas bumi. Batubara dijuluki juga sebagai emas hitam pada masa itu sehingga para pengusaha dari skala kecil sampai besar, baik domestik maupun internasional berbondong-bondong terjun ke bisnis batubara. Saat ini, meskipun harga batubara tidak sefantastis pada era 2004 sampai dengan akhir 2006, namun pengusahaan batubara di Indonesia masih tetap dianggap bisnis yang sangat prospektif di kalangan pengusaha.
Berkenaan dengan hal tersebut di atas, Pemerintah pada akhirnya dengan persetujuan DPR mengesahkan UU No. 4 Tahun 2009 tentang Pertambangan Mineral Dan Batubara yang dapat memberikan landasan hukum bagi langkahlangkah pembaruan dan penataan kembali kegiatan pengelolaan dan pengusahaan pertambangan mineral dan batubara.

Pemberlakuan UU No. 4 Tahun 2009 memiliki dampak positif, di antaranya dapat memberikan keberpihakan kepada perusahaan pertambangan nasional dari hulu sampai ke hilir. Konsep manajemen Wilayah Umum Pertambangan ("WUP") yang melibatkan Pemerintah Pusat, Pemerintah Daerah dan DPR diharapkan dapat mengatasi masalah tumpang tindih lahan dengan sektor lain seperti kehutanan dan pertanian. Selain itu, ketentuan pelelangan dalam mendapatkan Izin Usaha Pertambangan ("IUP") akan memberikan peluang bagi perusahaan pertambangan yang profesional dan serius. Dampak positif lainnya adalah UU No. 4 Tahun 2009 memberikan prioritas khusus kepada BUMN untuk mengusahakan wilayah pencadangan negara melalui IUP Khusus. Selain itu, ketentuan tentang keharusan mengolah di dalam negeri merupakan peluang bagi perusahaan pertambangan dalam negeri untuk melakukan pengolahan dan pemurnian hasil tambang dari pemegang IUP lain.

Mineral dan batubara yang merupakan sumber daya alam dikuasai oleh negara, oleh karenanya pengelolaannya harus memberi nilai tambah bagi perekonomian nasional 
guna mencapai kemakmuran dan kesejahteraan rakyat. Untuk mencapai tujuan di atas, maka pengelolaan pertambangan mineral dan batubara harus berazaskan manfaat, keadilan dan keseimbangan serta keberpihakan kepada kepentingan bangsa sesuai ketentuan Undang-Undang No. 4 Tahun 2009 tentang Pertambangan Mineral dan Batubara.

Secara eksplisit UU No. 4 Tahun 2009 menghormati keberadaan Perjanjian Karya Pengusahaan Pertambangan Batubara ("PKP2B") dan Kontrak Karya ("KK") yang telah ada pada saat diundangkannya UU No. 4 Tahun 2009 dengan tetap diberlakukannya KK dan PKP2B sampai dengan masa berakhirnya kontrak/perjanjian tersebut sebagaimana ketentuan tentang peralihan pada UU No. 4 Tahun 2009 dan wajib melakukan penyesuaian selambat-lambatnya 1 (satu) tahun sejak UU No. 4 Tahun 2009 tersebut diundangkan pada tanggal 12 Januari 2009 (UU No. 4 Tahun 2009, Pertambangan Mineral Dan Batubara, pasal 169) :

1. Perjanjian Karya Pengusahaan Pertambangan Batubara (PKP2B) yang telah ada sebelum berlakunya UndangUndang ini tetap diberlakukan sampai jangka waktu berakhirnya kontrak/perjanjian.

2. Ketentuan yang tercantum dalam PKP2B sebagaimana dimaksud pada huruf a disesuaikan selambatlambatnya 1 (satu) tahun sejak Undang-undang ini diundangkan kecuali mengenai penerimaan negara.

3. Pengecualian terhadap penerimaan negara sebagaimana dimaksud pada huruf $b$ adalah upaya peningkatan penerimaan negara.

Dari penjelasan Latar Belakang di atas, maka yang menjadi Identifikasi Masalah dalam makalah ini adalah sebagai berikut:

1. Apa maksud dan pengertian dari hukum dan perjanjian?

2. Apa jenis-jenis dan pengertian dari hukum perjanjian, terutama Perjanjian Karya Pengusahaan Pertambangan Batubara (PKP2B)?

3. Bagaimana penerapan hukum perjanjian di Indonesia secara umum serta jika ditinjau dalam perspektif Perjanjian Karya Pengusahaan Pertambangan Batubara (PKP2B)?

\section{Tinjauan Pusataka}

Perjanjian Dalam Hukum Perdata

Dalam hukum asing dijumpai istilah overeenkomst (bahasa Belanda), contract/ agreement (bahasa Inggris), dan sebagainya yang merupakan istilah yang dalam hukum kita dikenal sebagai "kontrak" atau "perjanjian". Umumnya dikatakan bahwa istilah-istilah tersebut memiliki pengertian yang sama, sehingga tidak mengherankan apabila istilah tersebut digunakan secara bergantian untuk menyebut sesuatu konstruksi hukum.

Istilah kontrak atau perjanjian dapat kita jumpai di dalam KUHP, bahkan didalam ketentuan hukum 
tersebut dimuat pula pengertian kontrak atau perjanjian. Disamping istilah tersebut, kitab undang-undang juga menggunakan istilah perikatan, perutangan, namun pengertian dari istilah tersebut tidak diberikan.

Pengertian perjanjian yang dikemukakan oleh Yahya Harahap adalah: "Perjanjian mengandung pengertian atau suatu hubungan hukum kekayaan harta benda antara dua orang atau lebih, yang memberi kekuatan hak atau sesuatu untuk memperoleh prestasi atau sekaligus kewajiban pada pihak lain untuk menunaikan kewajiban pada pihak lain untuk memperoleh suatu prestasi".

Sedangkan menurut Tahir Tungadi bahwa, "Perjanjian adalah persetujuan atau sepakat untuk menimbulkan, merubah atau menghapuskan hubungan hukum di lapangan hukum harta benda".

Pembahasan Hukum Perjanjian dalam makalah ini tidak terlepas dari konsep perjanjian yang berlaku di Indonesia yang bersumber dari Kitab Undang-undang Hukum Perdata. Hal ini disebabkan kesepakatan para pihak yang dituangkan dalam suatu perjanjian merujuk kepada ketentuan pasal-pasal dalam Kitab Undangundang Hukum Perdata Buku Ketiga tentang Perikatan sebagaimana dijelaskan dalam pasal 1313 KUH Perdata yang menyatakan Perjanjian adalah suatu perbuatan dimana satu orang atau lebih mengikatkan dirinya terhadap satu orang atau lebih. Oleh karena itu, tidak salah jika Kartini Muljadi dan Gunawan Widjaja dalam bukunya Perikatan yang Lahir dari Perjanjian menyebutkan suatu perjanjian adalah: 1) suatu perbuatan, 2) antara sekurangkurangnya dua orang (jadi dapat lebih dari dua orang), perbuatan tersebut melahirkan perikatan diantara dua pihak yang berjanji tersebut.

Adapun yang menjadi unsur perjanjian adalah sebagai berikut:

a) Ada para pihak

b) Ada persetujuan antara pihakpihak tersebut

c) Ada tujuan yang akan dicapai

d) Ada prestasi yang akan dilaksanakan

e) Ada bentuk tertentu,baik lisan maupun tulisan

f) Ada syarat-syarat tertentu.

\section{Syarat Sah Perjanjian}

\section{Menurut KUH Perdata}

Sahnya suatu perjanjian dikelompokkan dalam dua kelompok, yaitu syarat subyektif dan syarat obyektif. Syarat subyektif yaitu syarat yang menyangkut para pihak dan apabila syarat subyektif dalam suatu perjanjian tidak terpenuhi maka perjanjian tersebut dapat dibatalkan (vernietigbaar), selama perjanjian yang mengandung cacat subyektif belum dibatalkan, maka ia tetap mengikat para pihak layaknya perjanjian yang sah.

Sedangkan syarat obyektif adalah syarat yang menyangkut obyek perjanjian sebagaimana dalam Pasal 1320 KUHPerdata, dengan ketentuan:
a) Adanya kesepakatan dari pihak-pihak yang membuat perjanjian.
b) Adanya kemampuan untuk membuat perjanjian.



c) Adanya obyek atau hal tertentu yang diperjanjikan.
d) Tidak dilarang oleh undang-undang atau adanya sebab yang halal.

Apabila suatu perjanjian tidak memenuhi syarat obyektif dari suatu perjanjian maka akibat hukumnya adalah perjanjian tersebut batal demi hukum (null and void) (J. Satrio).

\section{Jenis pengusahaan pertambangan batubara di Indonesia}

Terdapat 2 (dua) skema pengusahaan pertambangan batubara berdasarkan UU No. 11 Tahun 1967 dan PP No. 32 Tahun 1969 (PP No. 32 Tahun 1969) :

\section{a) Perjanjian Karya \\ Pengusahaan Pertambangan Batubara (PKP2B)}

Kontrak kerja sama pengusahaan pertambangan antara Instansi Pemerintah/Perusahaan Negara selaku pemegang Kuasa Pertambangan dan pengusaha sebagai kontraktor.

\section{b) Kuasa Pertambangan (KP)}

Wewenang yang diberikan kepada badan/perseorangan untuk melaksanakan usaha pertambangan.

Dimana dalam perkembangan selanjutnya, ketentuan pengusahaan pertambangan diatur dalam UU No. 4 Tahun 2009 tentang Pertambangan Mineral Dan Batubara yang dapat memberikan landasan hukum bagi langkah-langkah pembaruan dan penataan kembali kegiatan pengelolaan dan pengusahaan pertambangan mineral dan batubara.

\section{Pembahasan \\ 1. Pengertian Hukum dan Perjanjian}

a. Pengertian Hukum

Menurut Van Kant, (http://www.scribd.com) hukum ialah keseluruhan peraturan hidup yang bersifat memaksa untuk melindungi kepentingan manusia didalam masyarakat. Peraturan dalam menjalankan kehidupan diperlukan untuk melindungi kepentingan dengan tertib.

Menurut Utrecht, hukum adalah himpunan peraturan (baik berupa perintah maupun larangan) yang mengatur tata tertib dalam suatu masyarakat dan seharusnya ditaati oleh anggota masyarakat yang bersangkutan. Oleh karena itu, pelanggaran petunjuk hidup tersebut dapat menimbulkan tindakan dari pihak pemerintah

Menurut Wiryono Kusumo, hukum adalah keseluruhan peraturan baik yang tertulis maupun tidak tertulis yang mengatur tata tertib dalam masyarakat dan terhadap pelanggarnya umumnya dikenakan sanksi. Sedangkan tujuan dari hukum adalah untuk mengadakan keselamatan, kebahagiaan, dan ketertiban dalam masyarakat. Menurut

Mochtar Kusumaatmadja, hukum merupakan keseluruhan asas-asas dan kaidahkaidah yang mengatur kehidupan manusia dalam masyarakat, dan juga mencakupi lembaga-lembaga (institutions) dan proses-proses (processes) yang mewujudkan berlakunya kaidah-kaidah itu dalam kenyataan.

\section{Menurut}

Wignyosoebroto, 
(http://mitrahukum.org) tidak ada konsep tunggal mengenai apa yang disebut hukum, karena sebenarnya hukum terdiri dari 3 konsep : hukum sebagai asas moralitas, hukum sebagai kaidah-kaidah positif yang berlaku pada waktu dan tempat tertentu dan hukum dikonsepkan sebagai institusi yang riil dan fungsional dalam sistem kehidupan bermasyarakat.

Menurut Hans Kelsen, hukum adalah sebuah ketentuan sosial yang mengatur perilaku mutual antar manusia, yaitu sebuah ketentuan tentang serangkaian peraturan yang mengatur perilaku tertentu manusia dalam hal ini berarti sebuah sistem norma, jadi hukum itu sendiri adalah ketentuan.

\section{b. Pengertian Perjanjian}

Sementara salah satu dasar teori dan pengertian dari perjanjian adalah suatu rangkaian dari sebuah ketentuan yang merupakan salah satu bentuk dari norma individual mengenai hak sipil yang terkait dengan hukum perdata. Individu melalui perjanjian dimungkinkan ikut dalam proses hukum sehingga diakui sebagai bagian dari tata aturan hukum yang memiliki karakter hukum, hal ini sebagaimana pandangan Hans Kelsen di atas yang menyatakan bahwa hukum adalah suatu ketentuan.

M. Yahya Harahap mengemukakan bahwa perjanjian (adanya debitur dan kreditur) yang bersifat perdata (civiele verbintenis) melekat prinsip pemaksaan, yaitu apabila debitur tidak memenuhi prestasi secara sukarela maka kreditur memiliki hak untuk memaksakan pemenuhan prestasi tersebut, inilah yang disebut "afdwangbaarheid". Pemenuhan prestasi dapat dipaksakan kepada debitur melalui alat kekuasaan/pejabat pengadilan dengan mempergunakan prosedur sebagaimana ditentukan dalam Kitab Undang-undang Hukum Acara Perdata. Ini berarti secara material hukum perjanjian telah menetapkan "hak kekuasaan" kreditur untuk memperoleh prestasi yang diperjanjikan. Dan untuk memperoleh hak material atas prestasi, kreditur dilengkapi dengan "hak kekuasaan melakukan aksi" sebagai upaya hukum terhadap hak material atas prestasi. Jadi kreditur diberi hak gugat atau aksi untuk memperoleh hak material atas prestasi dengan mempergunakan upaya hukum yang diatur dalam hukum acara (process recht) (Yahya Harahap, 1986).

Menurut Prof. Subekti (1996), definisi perjanjian: "Suatu peristiwa dimana seseorang berjanji kepada seorang lain atau dimana dua orang itu saling berjanji untuk melaksanakan sesuatu hal."

Disamping perjanjian, juga dikenal istilah lain yang berarti kesepakatan para pihak, diantaranya:

1) Persetujuan atau dalam bahasa Inggris disebut agreement. Sama seperti yang dimaksud oleh perjanjian dalam Pasal 1313 KUHPerdata, pengertian agreement dalam pengertian luas dapat berarti sebagai kesepakatan yang mempunyai konsekuensi hukum dan juga kesepakatan yang tidak mempunyai konsekuensi 
hukum. Agreement akan mempunyai kualitas atau pengertian perjanjian atau kontrak apabila ada akibat hukum yang dikenakan terhadap pelanggaran janji (breach of contract) dalam agreement tersebut. Dalam pengertian kesepakatan para pihak yang mempunyai konsekuensi hukum yang mengikat, maka agreement sama artinya dengan perjanjian (Subekti). Pengertian yang tercakup dalam Pasal 1313 KUHPerdata tidak menentukan bahwa perjanjian tersebut berbentuk tertulis maupun tidak tertulis. Sehingga terminologi "perjanjian" mencakup kedua bentuk tertulis maupun tidak tertulis tersebut.

2) Kontrak, berasal dari kata bahasa Inggris "contract". Adapun pengertian kontrak tidak disebut secara tegas dalam literatur hukum. Kontrak lebih merupakan istilah yang digunakan dalam perikatanperikatan bisnis disamping Memorandum of Understanding ("MoU") dan Letter of Intent ("LoI") yang pemakaian istilahnya bersifat khusus untuk perikatan bisnis. Kontrak yang dibuat dalam hubungan bisnis memiliki sifat yang tidak berbeda dengan perjanjian, yaitu ikatan yang memiliki akibat hukum.

Dalam KUHPerdata, perjanjian disebut juga dengan istilah “overeenkomst”(Belanda), diterjemahkan dengan perjanjian dan atau persetujuan, yaitu "contract/agreement" (Inggris) dan sebagainya, merupakan istilah yang dalam hukum kita dikenal sebagai "kontrak" atau "perjanjian". Umumnya dikatakan bahwa istilahistilah tersebut memiliki pengertian yang sama, sehingga tidak mengherankan apabila istilah tersebut digunakan secara bergantian untuk menyebut suatu konstruksi hukum.

Menyimak judul Buku III titel kedua tentang "Perikatan-perikatan yang lahir dari Kontrak atau Perjanjian" yang dalam bahasa Belanda berbunyi "Van verbintenissen die uit contract of overeenkomst geboren worden", dimana pengertian ini didukung oleh banyak sarjana, antara lain: Hofmann dan J. Satrio (1992), Soetojo Prawirohamidjojo dan Marthalena Pohan (1978), Mariam Darus Badrulzaman (1996), Purwahid Patrik (1994) dan Tirtodiningrat (R.M. Suryodiningrat, 1985) yang menggunakan istilah kontrak dan perjanjian dalam pengertian yang sama.

Subekti (1996) menganggap istilah kontrak mempunyai pengertian lebih sempit daripada perjanjian/perikatan, karena kontrak ditujukan kepada perjanjian/perikatan yang tertulis. Sedangkan Pothier membedakan contract dan convention (pacte). Disebut convention yaitu perjanjian antara dua orang atau lebih untuk menciptakan, menghapuskan atau merubah perikatan, adapun contract adalah perjanjian yang mengharapkan terlaksananya perikatan.

Argumentasi kritis mengenai penggunaan istilah kontrak atau 
perjanjian disumbangkan oleh Peter Mahmud Marzuki (2003) dengan melakukan perbandingan terhadap pengertian kontrak atau perjanjian dalam sistem Anglo-American.

Sistematika Buku III tentang Verbintenissenrecht

(hukum

Perikatan) mengatur mengenai overeenkomst yang kalau diterjemahkan ke dalam Bahasa Indonesia berarti perjanjian. Dalam konsep kontinental, penempatan pengaturan perjanjian pada Buku III KUHPerdata tentang Hukum Perikatan mengindikasikan bahwa perjanjian memang berkaitan dengan masalah Harta Kekayaan (Vermogen). Pengertian perjanjian ini mirip dengan contract pada konsep AngloAmerican yang selalu berkaitan dengan bisnis. Di dalam pola pikir Anglo-American, perjanjian yang bahasa Belanda-nya adalah overeenkomst dan dalam Bahasa Inggris disebut agreement mempunyai pengertian lebih luas dari contract, karena mencakup halhal yang berkaitan dengan bisnis atau bukan bisnis. Untuk agreement yang berkaitan dengan bisnis disebut contract, sedangkan untuk yang tidak terkait dengan bisnis hanya disebut agreement.

Wirjono Prodjodikoro

memberikan definisi perjanjian sebagai suatu hubungan hukum mengenai harta benda antara dua pihak, dalam mana suatu pihak berjanji atau dianggap berjanji untuk melakukan suatu hal atau untuk tidak melakukan sesuatu hal, sedang pihak lain berhak menuntut pelaksanaan janji itu (Wirjono Prodjodikoro, 1986).
Abdul Kadir Muhammad memberikan definisi perjanjian sebagai suatu persetujuan dengan mana dua orang pihak atau lebih mengikatkan diri untuk melaksanakan suatu hal dalam lapangan harta kekayaan (Abdulkadir Muhammad, 2000).

Tahir Tungadi memberikan definisi perjanjian sebagai suatu persetujuan atau sepakat untuk menimbulkan, merubah atau menghapuskan hubungan hukum di lapangan hukum harta benda (Tungadi, 1979).

Rutten memberikan definisi perjanjian sebagai suatu perbuatan hukum yang terjadi sesuai dengan formalitas-formalitas dari peraturan hukum yang ada, tergantung dari persesuaian pernyataan kehendak dua atau lebih orang-orang yang ditujukan untuk timbulnya akibat hukum demi kepentingan salah satu pihak atas beban pihak lain atau demi kepentingan dan atas beban masingmasing pihak secara timbal balik".

Sementara menurut adat, "Perjanjian adalah dimana pemilik rumah memberikan ijin kepada orang lain untuk mempergunakan rumahnya sebagai tempat kediaman dengan pembayaran sewa dibelakang (atau juga dapat terjadi pembayaran dimuka)".

Pengertian perjanjian menurut Pasal 1313 KUHPerdata didefinisikan sebagai suatu perbuatan hukum dengan mana salah satu orang atau lebih mengikatkan dirinya terhadap satu orang lain atau lebih, oleh karenanya Kartini Muljadi dan Gunawan Widjaja dalam bukunya yang berjudul "Perikatan yang Lahir dari Perjanjian" menyebutkan suatu 
perjanjian adalah : 1) suatu perbuatan 2) antara sekurangkurangnya dua orang (jadi dapat lebih dari dua orang) dan perbuatan tersebut melahirkan perikatan diantara dua pihak yang berjanji tersebut.

Merujuk sistematika buku III KUHPerdata tentang Verbintenissenrecht (Hukum Perikatan), berbagai kepustakaan hukum Indonesia memakai bermacam-macam istilah untuk menerjemahkan "verbintenis" dan "overeenkomst" :

1) Verbintenis (perikatan) dan overeenkomst (persetujuan) digunakan oleh Subekti dan Tjiptosudibjo (1994).

2) Verbintenis (perutangan) dan overeenkomst (perjanjian) digunakan oleh Utrecht (1994).

3) Verbintenis (perjanjian) dan overeenkomst (persetujuan) digunakan oleh Achmad Ichsan (1994).

Kemudian dapat disimpulkan (R. Setiawan, 1994):

1) Terdapat 3 (tiga) istilah untuk Verbintenis, yaitu perikatan, perutangan dan perjanjian.

2) Terdapat 2 (dua) istilah untuk Overeenkomst, yaitu perjanjian dan persetujuan.

Prof. Subekti menjabarkan pengertian perikatan: "Suatu perhubungan hukum antara dua orang atau dua pihak, berdasarkan mana pihak yang satu berhak menuntut sesuatu hal dari pihak lain, dan pihak yang lain berkewajiban untuk memenuhi tuntutan itu." (http://www.jurnalhukum.com).

Pitlo mendefinisikan perikatan: "Suatu hubungan hukum di dalam lapangan harta kekayaan antara dua orang atau lebih dimana salah satu pihak berkewajiban dan pihak lainnya berhak atas suatu prestasi."

Pasal 1233 Buku III KUHPerdata mengemukakan bahwa perikatan timbul dari persetujuan atau undang-undang (Agustinus Dawarja dan Aksioma Lase) dan menunjukkan bahwa setiap kewajiban yang ada pada suatu perikatan dapat terwujud karena dua hal. Pertama, karena ditentukan oleh undang-undang dan kedua karena memang dikehendaki oleh para pihak dengan mengadakan atau membuat suatu perjanjian. Dengan demikian, setiap pihak yang membuat perjanjian dengan pihak lainnya secara sadar memang bermaksud untuk mengikatkan dirinya untuk melaksanakan suatu kewajiban dalam lapangan harta kekayaan yang merupakan perikatan atau utang bagi dirinya terhadap pihak lawannya dalam perjanjian tersebut (Gunawan Wijaya dan Kartini Muljadi, 2004).

Pasal 1234 Buku III
KUHPerdata menyatakan bahwa "tiap-tiap perikatan adalah untuk memberikan sesuatu, untuk berbuat sesuatu atau tidak untuk berbuat sesuatu". Pasal 1235 KUHPerdata menyebutkan : "Dalam tiap-tiap perikatan untuk memberikan sesuatu, termaktub kewajiban si berutang untuk menyerahkan kebendaan yang bersangkutan sampai pada saat penyerahan". Dari pasal tersebut di atas dapat disimpulkan bahwa dalam suatu perikatan, pengertian "memberi sesuatu" mencakup pula kewajiban untuk menyerahkan barangnya dan 
memeliharanya hingga waktu penyerahan.

Istilah "memberikan sesuatu" sebagaimana disebutkan di dalam Pasal 1235 KUHPerdata tersebut dapat mempunyai dua pengertian, yaitu :

1) Penyerahan kekuasaan belaka atas barang yang menjadi obyek perjanjian.

2) Penyerahan hak milik atas barang yang menjadi obyek perjanjian, yang dinamakan penyerahan yuridis.

Wujud prestasi terdiri dari "berbuat sesuatu" dan "tidak berbuat sesuatu". Pengertian berbuat sesuatu adalah melakukan suatu perbuatan yang telah ditetapkan dalam perjanjian, sedangkan tidak berbuat sesuatu adalah tidak melakukan sesuatu perbuatan sebagaimana juga yang telah ditetapkan dalam perjanjian. Manakala para pihak telah menunaikan prestasinya maka perjanjian tersebut akan berjalan sebagaimana mestinya tanpa menimbulkan persoalan, namun kadangkala ditemui bahwa debitur tidak bersedia melakukan atau menolak memenuhi prestasi sebagaimana yang telah ditentukan dalam perjanjian.

Salah satu unsur dari perikatan adalah adanya suatu isi atau tujuan perikatan itu sendiri, yakni suatu prestasi yang terdiri dari :

1) Memberikan sesuatu, misalnya membayar harga, menyerahkan barang.

2) Berbuat sesuatu, misalnya memperbaiki barang yang rusak, membangun rumah, melukis suatu lukisan untuk pemesan.
3) Tidak berbuat sesuatu, misalnya perjanjian tindak akan mendirikan suatu bangunan, perjanjian tidak akan menggunakan merk dagang tertentu.

Prestasi dalam suatu perikatan tersebut harus memenuhi syaratsyarat:

1) Suatu prestasi harus merupakan suatu prestasi yang tertentu atau sedikitnya dapat ditentukan jenisnya, sehingga tanpa adanya ketentuan, sulit untuk menentukan apakah debitur telah memenuhi prestasi atau belum.

2) Prestasi harus dihubungkan dengan suatu kepentingan, dimana tanpa suatu kepentingan orang tidak dapat mengadakan tuntutan.

3) Prestasi harus diperbolehkan oleh Undang-undang, kesusilaan dan ketertiban umum.

4) Prestasi harus dilaksanakan.

Pengertian istilah debitur yaitu pihak yang wajib memenuhi tuntutan atau pihak berhutang dan kreditur yaitu pihak yang berhak menuntut atau pihak berpiutang.

Debitur dikatakan wanprestasi manakala ia karena kesalahannya sendiri tidak melaksanakan prestasi atau melakukan sesuatu yang menurut perjanjian tidak diperbolehkan untuk dilakukan. Jadi wanprestasi adalah tidak dipenuhinya perikatan hukum, tidak melakukan apa yang dijanjikannya atau ingkar janji, melanggar perjanjian serta melakukan sesuatu yang tidak boleh dilakukannya.

Perkataan wanprestasi berasal dari bahasa Belanda, yang artinya 
prestasi buruk. Suatu keadaan dikarenakan kelalaian atau kesalahannya, seorang debitur tidak dapat memenuhi prestasi seperti yang telah ditentukan dalam perjanjian (Nindyo Pramono, 2003).

Menurut R. Subekti, melakukan prestasi tetapi tidak sebagaimana mestinya juga dinamakan wanprestasi. Yang menjadi persoalan adalah sejak kapan debitur dapat dikatakan wanprestasi. Mengenai hal tersebut perlu dibedakan wujud atau bentuk prestasinya. Bentuk prestasi sangat menentukan sejak kapan seorang debitur dapat dikatakan telah wanprestasi.

Dalam hal wujud prestasinya "memberikan sesuatu", maka perlu dipertanyakan apakah di dalam perjanjian telah ditentukan atau belum mengenai tenggang waktu pemenuhan prestasinya. Apabila tenggang waktu pemenuhan prestasi sudah ditentukan dalam perjanjian, maka menurut Pasal 1238 KUHPerdata, debitur sudah dianggap wanprestasi dengan lewatnya waktu pemenuhan prestasi tersebut. Sedangkan bila tenggang waktunya tidak dicantumkan dalam perjanjian, maka dipandang perlu untuk terlebih dahulu memperingatkan debitur guna memenuhi kewajibannya dan jika tidak dipenuhi, maka ia telah dinyatakan wanprestasi.

Debitur juga dinyatakan telah wanprestasi apabila sudah ada somasi (in gebreke stelling). Adapun bentuk-bentuk somasi menurut pasal 1238 KUH Perdata adalah (Nindyo Pramono) :

1) Surat perintah

Surat perintah tersebut berasal dari hakim yang biasanya berbentuk penetapan. Dengan surat penetapan ini juru sita memberitahukan secara lisan kepada debitur kapan selambatlambatnya dia harus berprestasi. Hal ini biasa disebut "exploit juru Sita".

2) Akta sejenis

Akta ini dapat berupa akta dibawah tangan maupun akta notaris.

3) Tersimpul dalam perikatan itu sendiri

Maksudnya sejak pembuatan perjanjian, kreditur sudah menentukan saat adanya wanprestasi.

Dalam perkembangannya, suatu somasi atau teguran terhadap debitur yang melalaikan kewajibannya dapat dilakukan secara lisan akan tetapi untuk mempermudah pembuktian dihadapan hakim apabila masalah tersebut berlanjut ke pengadilan maka sebaiknya diberikan peringatan secara tertulis.

Dalam keadaan tertentu somasi tidak diperlukan untuk dinyatakan bahwa seorang debitur melakukan wanprestasi yaitu dalam hal adanya batas waktu dalam perjanjian (fatal termijn), prestasi dalam perjanjian berupa tidak berbuat sesuatu, debitur mengakui dirinya wanprestasi.

Seorang debitur dianggap wanprestasi bila ia telah memenuhi ketentuan-ketentuan :

1) Tidak melakukan apa yang disanggupi akan dilakukan;

2) Melaksanakan apa yang dijanjikannya, tetapi tidak sebagaimana dijanjikan;

3) Melakukan apa yang dijanjikan tetapi terlambat;

4) Melakukan sesuatu yang menurut perjanjian tidak boleh dilakukannya. 
Pendapat lain mengenai syaratsyarat terjadinya wanprestasi, yaitu:

1) Debitur sama sekali tidak berprestasi, dalam hal ini kreditur tidak perlu menyatakan peringatan atau teguran karena hal ini percuma sebab debitur memang tidak mampu berprestasi.

2) Debitur berprestasi tidak sebagaimana mestinya, dalam hal ini debitur sudah beritikad baik untuk melakukan prestasi, tetapi ia salah dalam melakukan pemenuhannya.

3) Debitur terlambat berprestasi, dalam hal ini debitur masih mampu memenuhi prestasi namun terlambat dalam memenuhi prestasi tersebut.

Apabila debitur melakukan wanprestasi maka ada beberapa sanksi yang dapat dijatuhkan kepada debitur, yaitu :

1) Membayar kerugian yang diderita kreditur;

2) Pembatalan perjanjian;

3) Peralihan resiko;

4) Membayar biaya perkara apabila sampai diperkarakan dimuka hakim.

Bahwa kerugian yang harus diganti meliputi kerugian yang dapat diduga dan merupakan akibat langsung dari wanprestasi, artinya ada hubungan sebab-akibat antara wanprestasi dengan kerugian yang diderita. Berkaitan dengan hal ini ada dua sarjana yang mengemukakan teori tentang sebab-akibat yaitu :

a) Conditio Sine qua Non (Von Buri)

Menyatakan bahwa suatu peristiwa A adalah sebab dari peristiwa B (peristiwa lain) dan peristiwa B tidak akan terjadi jika tidak ada peristiwa A.

b) Adequated Veroorzaking (Von Kries)

Menyatakan bahwa suatu peristiwa $\mathrm{A}$ adalah sebab dari peristiwa B (peristiwa lain). Bila peristiwa A menurut pengalaman manusia yang normal diduga mampu menimbulkan akibat (peristiwa B).

Dari kedua teori diatas maka yang lazim dianut adalah teori Adequated Veroorzaking karena pelaku hanya bertanggung jawab atas kerugian yang selayaknya dapat dianggap sebagai akibat dari perbuatan itu disamping itu teori inilah yang paling mendekati keadilan.

Disamping debitur harus menanggung hal tesebut diatas, maka yang dapat dilakukan oleh kreditur dalam menghadapi debitur yang wanprestasi ada lima kemungkinan sebagai berikut :

1) Dapat menuntut pemenuhan perjanjian, walaupun pelaksanaannya terlambat.

2) Dapat menuntut penggantian kerugian, berdasarkan Pasal 1243 KUH Perdata, ganti rugi tersebut dapat berupa biaya, rugi atau bunga.

3) Dapat menuntut pemenuhan dan penggantian kerugian.

4) Dapat menuntut pembatalan atau pemutusan perjanjian.

5) Dapat menuntut pembatalan dan penggantian kerugian.

Perikatan dapat meliputi dua arti, yaitu pada satu sisi sebagai perjanjian yang memang konsekuensi hukumnya sangat tergantung pada 
pihak-pihak yang terikat didalamnya dan pada sisi lain merupakan perikatan yang mempunyai konsekuensi hukum yang jelas. Sekalipun perjanjian sebagai suatu perikatan muncul bukan dari undangundang tetapi memiliki kekuatan hukum yang sama dengan perikatan yang muncul dari undang-undang, yaitu berlaku sebagai undang-undang bagi mereka yang diikat didalamnya.

Pada dasarnya perikatan dan perjanjian adalah sama, yaitu merupakan hubungan hukum antara pihak-pihak yang diikat didalamnya, namun pengertian perikatan lebih luas dari perjanjian sebab hubungan hukum yang ada dalam perikatan munculnya tidak hanya dari perjanjian tetapi juga dari aturan perundang-undangan. Hal lain yang membedakan keduanya adalah bahwa perjanjian pada hakekatnya merupakan hasil kesepakatan para pihak, jadi sumbernya benar-benar kebebasan pihak-pihak yang ada untuk diikat dengan perjanjian sebagaimana diatur dalam Pasal 1338 KUHPerdata. Sedangkan perikatan yang mengikat karena diwajibkan oleh undang-undang, perbedaan pengertian antara perjanjian dan perikatan didasarkan karena lebih luasnya pengertian perikatan dibandingkan perjanjian. Artinya didalam hal pengertian perjanjian sebagai bagian dari perikatan, maka perikatan akan mempunyai arti sebagai hubungan hukum atau perbuatan hukum yang mengikat antara dua orang atau lebih, yang salah satu pihak mempunyai kewajiban untuk memenuhi prestasi tersebut. Bila salah satu pihak yang melakukan perikatan tersebut tidak melaksanakan atau terlambat melaksanakan prestasi, pihak yang dirugikan akibat dari perbuatan melawan hukum tersebut berhak untuk menuntut pemenuhan prestasi atau penggantian kerugian dalam bentuk biaya, ganti rugi dan bunga.

$$
\text { T. Antony Downes }
$$
mengemukakan bahwa "kontrak" sebagai salah satu konsep besar dalam hukum sangat sulit untuk didefinisikan karena akan berimplikasi kepada generalisasi yang bergantung kepada pengecualian dan ketidaklengkapan (subject to exceptions and incomplete), tetap mencoba memberikan pengertian atas "contract" yang paling tidak dapat memberikan indikasi dari ide pokok konsep tersebut, yaitu "perjanjian yang secara hukum dapat dipaksakan (contracts are legally enforceable agreements)". Tanggung jawab atas wanprestasi (breach of contract), oleh karenanya adalah tanggung jawab atas kegagalan dalam mentaati ketentuan dalam perjanjian dimaksud. "Secara hukum dapat dipaksakan" disini berarti bahwa hukum memberikan sanksi atas wanprestasi yang membedakannya dengan kesepakatan sosial biasa yang berada di luar hukum yang hanya mengikat secara kewajiban moral atau secara hukum kebiasaan. Lebih lanjut ditegaskan bahwa suatu perjanjian hanya akan dikategorikan sebagai kontrak jika para pihak berkeinginan untuk memiliki konsekuensi hukum yang berasal dari perjanjian tersebut (T. Antony Downes, 1997).

M. Yahya Harahap menyatakan bahwa perjanjian (verbintenis) 
sebagai suatu hubungan hukum kekayaan/harta benda antara dua orang atau lebih, yang memberi kekuatan hak pada satu pihak untuk memperoleh prestasi dan sekaligus mewajibkan pihak lain menunaikan prestasi. Sedangkan "persetujuan" atau "overeenkomst" bisa juga disebut "contract" tindakan seseorang atau lebih mengikatkan diri pada seseorang atau lebih. Tindakan/perbuatan (handeling) yang menciptakan persetujuan, berisi "pernyataan kehendak" (wils verklaring) antara para pihak. Namun perlu diingatkan, sekalipun Pasal 1313 KUHPerdata menyatakan bahwa kontrak atau persetujuan adalah tindakan atau perbuatan (handeling), tapi tindakan yang dimaksud dalam hal ini adalah tindakan atau perbuatan hukum (rehctshandeling). Sebab tidak semua tindakan/perbuatan memiliki akibat hukum (rectsgevolg) hanya tindakan hukum saja yang dapat menimbulkan akibat hokum (Yahya Harahap).

Dalam Kitab Undang Undang Hukum Perdata terdapat asas-asas yang perlu mendapat perhatian dalam membuat perjanjian, yaitu:

1) Asas Kontrak sebagai Hukum mengatur (aanvullen recht) adalah peraturan-peraturan hukum hukum yang berlaku bagi subjek hukum, misalnya para pihak dalam suatu kontrak. Akan tetapi, ketentuan hukum seperti ini tidak mutlak berlakunya, karena jika para pihak mengatur sebaliknya, maka yang berlaku adalah apa yang diatur oleh para pihak tersebut. Jadi, peraturan yang bersifat umum mengatur dapat disimpangi oleh para pihak. Pada prinsipnya hukum kontrak termasuk kategori hukum mengatur, yakni sebagian besar (meskipun tidak menyeluruh) dari hukum kontrak tersebut dapat disimpangi oleh para pihak dengan mengaturnya sendiri. Oleh karena itu, hukum kontrak ini disebut hukum yang mempunyai sistem terbuka (open system). Sebagai lawan dari hukum mengatur adalah hukum yang memaksa (dwingend recht, mandatory). Dalam hal ini yang dimaksud dengan hukum memaksa adalah aturan hukum yang berlaku secara memaksa atau mutlak, dalam arti tidak dapat disimpangi oleh para pihak yang terlibat dalam suatu perbuatan hukum, termasuk oleh para pihak dalam suatu kontrak.

2) Asas Kebebasan

Berkontrak (freedom of contract) merupakan konsekuensi dari berlakunya asas kontrak sebagai hukum mengatur. Dalam hal ini yang dimaksudkan dengan asas kebebasan berkontrak adalah suatu asas yang mengajarkan bahwa dalam suatu kontrak para pihak pada prinsipnya bebas untuk membuat atau tidak membuat kontrak, demikian juga kebebasanya untuk mengatur sendiri isi kontrak tersebut. Asas kebebasan berkontrak ini dibatasi oleh ramburambu hukum sebagai berikut :

a) harus memenuhi syarat sebagai suatu kontrak

b) tidak dilarang oleh undangundang

c) tidak bertentangan dengan kebiasaan yang berlaku

d) harus dilaksanakan dengan itikad baik

3) Asas Pacta Sunt Servanda 
Istilah "pacta sunt servanda" mempunyai arti bahwa janji itu mengikat, yang dimaksud dengan asas kebebasan berkontrak ini ialah bahwa kontrak yang dibuat secara sah oleh para pihak tersebut secara penuh sesuai isi kontrak tersebut. Istilah lain dari asas ini adalah "my word is my bonds", yang artinya dalam bahasa Indonesia bahwa jika sapi dipegang talinya, jika manusia dipegang mulutnya, mengikat secara penuh atas kontrak-kontrak yang dibuat oleh para tersebut oleh hukum kekuatanya dianggap sama saja dengan kekuatan mengikat dari suatu undang-undang. Oleh karena itu, apabila suatu pihak dalam kontrak yang telah dibuatnya oleh hukum disediakan ganti rugi atau bahkan pelaksaan kontrak secara paksa.

\section{4) Asas Konsensual}

Yang dimaksud dengan asas konsensual dari suatu kontrak adalah bahwa jika suatu kontrak telah dibuat, maka dia telah sah dan mengikat secara penuh, bahkan pada prinsipnya persyaratan tertulis pun tidak disyaratkan oleh hukum, kecuali untuk beberapa jenis kontrak tertentu, yang memang dipersyaratkan syarat tertulis.

\section{5) Asas Obligatoir}

Asas obligatori adalah suatu asas yang menetukan bahwa jika suatu kontrak telah dibuat, maka para pihak telah terikat, tetapi keterikatan itu hanya sebatas timbulnya hak dan kewajiban semata-mata, sedangkan prestasi belum dapat dipaksakan karena kontrak kebendaan (zakelijke overeenkomst) belum terjadi. Jadi, jika terhadap kontrak jual beli misalnya, maka dengan kontrak saja, hak milik belum berpindah, jadi baru terjadi kontrak obligatoir saja. Hak milik tersebut baru dapat berpindah setelah adanya kontrak kebendaan atau sering disebut serah terima (levering). Hukum kontrak di Indonesia memberlakukan asas obligatoir ini karena berdasarkan Kitab Undang-Undang Hukum Perdata. Kalaupun hukum adat tentang kontrak tidak mengakui asas obligatoir karena hukum adat memberlakukan asas kontrak riil, artinya suatu kontrak haruslah dibuat secara riil, dalah hal ini harus dibuat secara terang dan tunai. Kontrak harus dilakukan di depan pejabat tertentu, misalnya di depan penghulu adat atau ketua adat, yang sekaligus juga dilakukan levering-nya. Jika hanya sekedar janji saja, seperti dalam sistem obligatoir, dalam hukum adat kontrak semacam ini tidak mempunyai kekuatan sama sekali.

Suatu perjanjian dianggap sah dan mengikat, bila unsur-unsur dan syarat-syarat tertentu dalam perjanjian harus terpenuhi.

Unsur-unsur dalam perjanjian terdiri dari (ejurnal.ung.ac.id) :

1) Para pihak

2) Persetujuan antara pihakpihak tersebut

3) Tujuan yang akan dicapai

4) Prestasi yang akan dilaksanakan

5) Bentuk tertentu,baik lisan maupun tulisan

6) Syarat-syarat tertentu.

Syarat-syarat tertentu terdiri dari 4 (empat) unsur yang harus dipenuhi :

1) Adanya kesepakatan dari pihakpihak yang membuat perjanjian 
berupa persetujuan secara bebas dari pihak-pihak yang mengadakan perjanjian. Kehendak satu pihak haruslah juga kehendak pihak yang lain. Kesepakatan harus diberikan dalam keadaan sadar, bebas dan bertanggung jawab. Tiga hal yang dapat menyebabkan tidak tercapainya kesepakatan secara bebas, yaitu paksaan, khilaf dan penipuan.

a) Paksaan dapat berupa paksaan fisik maupun psikis. Paksaan psikis sudah terjadi apabila ada ancaman menakuti-nakuti. Ancaman yang dimaksud disini adalah ancaman yang melawan hukum. Apabila tidak melawan hukum, seperti ancaman gugatan atas kelalaian, maka tidak dapat dikatakan paksaan (Pasal 1324 BW)

b) Kekhilafan terjadi apabila pihak yang membuat perjanjian (salah satu atau keduanya) keliru mengenai sifat, harga, dan jenis obyek yang diperjanjikan. Kekeliruan di sini haruslah yang tidak diduga dan disadari serta adanya kencenderungan siapapun yang memberi persetujuan akan berada dalam kekeliruan. Atas hal ini dapat dimintakan pembatalan atas perjanjian yang telah dibuat.

c) Penipuan terjadi apabila salah satu pihak memberikan informasi yang tidak benar mengenai subyek maupun obyek yang diperjanjikan dengan tujuan untuk mempengaruhi pihak lainnya untuk memberikan persetujuan (Pasal 1328 BW).
2) Adanya kemampuan untuk membuat perjanjian. Yang dimaksud dengan kemampuan adalah memiliki pengetahuan dan kehendak terhadap hal yang diperjanjikan serta dianggap mampu mempertanggung jawabkan apa yang diperjanjikannya. Pada dasarnya setiap orang yang sudah dewasa dan berakal sehat mampu mengetahui dan menghendaki apa yang diperjanjikan. Pihak-pihak yang dianggap tidak mempunyai kemampuan dalam perjanjian menurut pasal 1330 KUHPerdata adalah :

a) Anak yang belum dewasa

b) Orang-orang yang di bawah pengampuan, yaitu orang yang tidak sehat akalnya, pemboros, orang yang lemah ingatannya Akibat dari perjanjian yang dibuat oleh pihak yang tidak cakap adalah batal demi hukum (Pasal 1446 BW).

3) Adanya obyek atau hal tertentu yang diperjanjikan. Obyek perjanjian harus jelas, apabila berupa barang maka harus jenis-jenis, jumlah, dan harganya. Paling tidak dari keterangan mengenai obyek, harus dapat ditetapkan apa yang menjadi hak dan kewajiban masing-masing pihak. Suatu perjanjian yang tidak menyebutkan obyeknya otomatis batal menurut hukum.

4) Tidak dilarang oleh undangundang atau adanya sebab yang halal. Maksudnya isi perjanjian tidak boleh bertentangan dengan perundang-undangan 
yang bersifat memaksa, ketertiban umum dan kesusilaan.

Sahnya causa dari suatu persetujuan ditentukan pada saat perjanjian dibuat. Perjanjian tanpa causa yang halal adalah batal demi hukum, kecuali ditentukan lain oleh undang-undang.

Persesuaian kehendak atau pernyataan kehendak dapat dinyatakan dengan lisan, tulisan/surat dan lain-lain. Pihak yang satu menawarkan atau memajukan "usul" (proposal), serta pihak yang lain menerima atau menyetujui usul tersebut. Jadi dalam persetujuan penerimaan/acceptance atau persetujuan usul. Dengan adanya penawaran/usul serta persetujuan oleh pihak lain atas usul, lahirlah "persetujuan" atau "kontrak" yang melahirkan "ikatan hukum" bagi para pihak.

Ewan Mc Kendrick, salah seorang sarjana hukum dari sistem hukum Common Law, terkait penawaran dan penerimaan mengemukakan bahwa pengadilan mengadopsi "mirror image rule" mengenai terjadinya kontrak. Oleh karena itu, harus terdapat penawaran jelas dan tegas yang disandingkan dengan penerimaan yang sama jelas dan tegasnya sebagai syarat (Ewan Mc Kendrick, 2003).

Perjanjian menuntut adanya itikad baik dari para pihak dalam perjanjian, oleh karena itu perjanjian yang disebabkan oleh sesuatu yang tidak halal, misalnya karena paksaaan atau tipu muslihat tidak memenuhi syarat sebagai suatu perjanjian.
Penegasan terhadap pemberlakuan perjanjian yang telah memenuhi syarat sahnya perjanjian, merupakan aturan hukum yang mengikat kedua belah pihak, ditegaskan dalam pasal 1338 KUHPerdata: suatu perjanjian merupakan suatu undang-undang bagi para pembuatnya. Berlakunya perjanjian sebagai sebuah undangundang mengikat bagi para pihak dan memaksa para pihak untuk melaksanakannya.

Resiko yang akan terjadi pada transaksi pinjam meminjam apabila tidak ada perjanjian yang jelas, maka terdapat kemungkinan salah satu pihak akan mangkir dari tanggung jawab untuk membayar kewajibannya. Inilah salah satu penyebab mengapa dikeluarkannya hukum perjanjian. Hukum perjanjian dikeluarkan dengan tujuan agar semua proses kerjasama yang terjadi dapat berjalan dengan lancar dan untuk mengurangin resiko terjadinya penipuan atau hal apapun yang beresiko merugikan salah satu pihak. Peranan hukum disini adalah sebagai pengatur atau sebagai penunduk para pelaku hukum agar tetap bertindak sesuai peraturan yang telah ditentukan, dan tentunya peraturan yang dimaksud adalah peraturan yang berlandaskan UUD, contohnya Pasal 13 ayat 20 KUHPerdata mengenai syarat-syarat sahnya perjanjian.

Hukum perjanjian dilakukan oleh dua pihak yang saling bekerjasama. Ketika mereka sepakat untuk melakukan kerja dengan disertai beberapa syarat(perjanjian) maka pada saat itu sudah terjadi hukum perjanjian. Sebagai contoh 
dan untuk memudahkan dalam penalaran,misalnya pada pasar uang hukum perjanjian dilakukan oleh kedua belah pihak, yaitu investor dan emiten. Dikeluarkannya hukum perjanjian adalah untuk melindungi investor dari berbagai resiko yang mungkin akan terjadi. Hukum perjanjian tidak hanya menyangkut masalah ekonomi. Hukum perjanjian juga mengatur berbagai kerjasama yang menyangkut dua pihak yang terkait. Misalnya hubungan antar Negara (bilateral maupun multilateral), pengalihan kekuasaan, mengatur harta warisan, perjanjian kontrak kerja, perjanjian perdamaian. Di Indonesia, tidak semua perjanjian yang isinya merupakan kesepakan murni antara dua belah pihak. Tetapi ada juga beberapa perjanjian yang didalamnya terdapat campur tangan pemerintah.

Hukum perjanjian merupakan sesuatu yang terbentuk dengan mempertimbangkan aspek-aspek yang akan terkait didalamnya.

Hukum perjanjian terbentuk dengan beberapa asas-asas perjanjian:

1) Asas Itikad Baik

Hukum perjanjian dibentuk dengan tujuan agar dapat memberikan manfaat bagi kedua belah pihak. Dengan harapan kedua belah pihak memberikan seluruh potensi, kemampuan, usaha dan prestasi mereka sesuai dengan yang tertera di dalam surat perjanjian.

2) Asas Konsensualitas

Perjanjian telah dinyatakan sah oleh kedua belah pihak dan bukan merupakan suatu perjanjian yang bersifat formalitas belaka.

3) Perjanjian Berlaku sebagai Undang-undang

Perjanjian yang telah dibuat dan sudah disahkan dianggap sebagai dasar mengikat kedua belah pihak untuk bertindak sesuai isi perjanjian.

4) Asas Kepribadian

Perjanjian dibuat hanya melibatkan kedua belah pihak saja dan tidak ada pihak ketiga yang dirugikan akibat perjanjian tersebut.

5) Kebebasan Berkontrak, meliputi

a) Kebebasan untuk membuat atau tidak membuat perjanjian

b) Kebebasan untuk memilih dengan siapa akan melakukan perjanjian

c) Kebebasan untuk menetukan obyek perjanjian

d) Kebebasan untuk menentukan bentuk perjanjian

Apabila azas-azas perjanjian telah terpenuhi, maka hukum perjanjian dapat dilaksanakan dengan membuat surat perjanjian dengan melampirkan identitas kedua belah pihak dan obyek perjanjian disertai dengan materai. Apabila obyek perjanjian menyangkut masalah seperti warisan, jual beli rumah dan atau tanah maka pengesahannya dilakukan dengan melibatkan notaris.

Jenis-jenis dan Pengertian Hukum Perjanjian Serta Perjanjian Karya Pengusahaan Pertambangan Batubara (PKP2B) Perjanjian Obligatoir 
Perjanjian yang mewajibkan seseorang untuk menyerahkan atau membayar sesuatu, meliputi:

1) Perjanjian dengan cuma-cuma dan perjanjian dengan beban

a) Perjanjian dengan cuma-cuma ialah suatu perjanjian dimana pihak yang satu memberikan suatu keuntungan kepada yang lain tanpa menerima suatu manfaat bagi dirinya sendiri. (Pasal 1314 ayat KUHPerdata).

b) Perjanjian dengan beban ialah suatu perjanjian dimana salah satu pihak memberikan suatu keuntungan kepada pihak lain dengan menerima suatu manfaat bagi dirinya sendiri.

2) Perjanjian sepihak dan

3) perjanjian timbal balik

Perjanjian sepihak adalah suatu perjanjian dimana hanya terdapat kewajiban pada salah satu pihak saja.

a) Perjanjian timbal balik ialah suatu perjanjian yang memberi kewajiban dan hak kepada kedua belah pihak.

4) Perjanjian konsensuil, formal dan riil

a) Perjanjian konsensuil ialah perjanjian dianggap sah apabila ada kata sepakat antara kedua belah pihak yang mengadakan perjanjian tersebut.

b) Perjanjian formil ialah perjanjian yang harus dilakukan dengan suatu bentuk tertentu, yaitu dengan cara tertulis.

c) Perjanjian riil ialah suatu perjanjian dimana selain diperlukan adanya kata sepakat, harus diserahkan.

d) Perjanjian bernama, tidak bernama dan campuran a) Perjanjian bernama adalah suatu perjanjian dimana Undang Undang telah mengaturnya dengan kententuan-ketentuan khusus yaitu dalam Bab $\mathrm{V}$ sampai bab XIII KUHPerdata ditambah titel VIIA.

b) Perjanjian tidak bernama ialah perjanjian yang tidak diatur secara khusus.

c) Perjanjian campuran ialah perjanjian yang mengandung berbagai perjanjian yang sulit dikualifikasikan.

\section{Perjanjian Non Obligatoir}

Perjanjian yang tidak mewajibkan seseorang untuk menyerahkan atau membayar sesuatu, terdiri:

\section{1) Zakelijk overeenkomst,} adalah perjanjian yang menetapkan dipidindahkannya suatu hak dari seseorang kepada orang lain. Misalnya balik nama hak atas tanah.

2) Bevifs overeenkomst adalah perjanjian untuk membuktikan sesuatu.

3) Liberatoir overeenkomst adalah perjanjian dimana seseorang membebaskan pihak lain dari suatu kewajiban.

4) Vaststelling overenkomst adalah perjanjian untuk mengakhiri keraguan mengenai isi dan luas perhubungan hukum di antara para pihak.

\section{Perjanjian yang dilarang berdasar UU No. 5 Tahun 1999}

Perjanjian bersama dan
(Oligopoli dan Monopoli) 
kegiatan yang mengarah pada penguasaan pangsa pasar.

2) Perjanjian bersama untuk menetapkan harga (Price Fixing/penetapan harga).

3) Perjanjian yang mengakibatkan diskriminasi harga (Price Discrimination/ (satu atau beberapa pembeli mendapatkan harga lebih rendah diskriminasi harga) atau lebih tinggi dari lainnya).

4) Perjanjian dan kegiatan penetapan harga di bawah (Jual rugi/Predatory harga pasar (jual rugi), untuk menyingkirkan pesaing Pricing).

5) Perjanjian harga secara vertikal (pemasok menetapkan Resale Price Maintenance harga jual dan dilarang menurunkan harga).

6) Perjanjian

(horizontal) pembagian wilayah pasar (Pembagian wilayah pasar) (contoh dulu : Asosiasi Semen).

7) Perjanjian melakukan boikot yang menghalangi (Boikot) pelaku usaha lain masuk pasar.

8) Perjanjian (horizontal) untuk menetapkan/ (Kartel) mempengaruhi harga, produksi dan pemasaran.

9) Perjanjian membentuk gabungan usaha (lebih besar) (Trust) untuk memperkuat anggota pelaku perjanjian, mengontrol produksi dan pemasaran.

10) Perjanjian (vertikal) untuk (Oligopsoni) menguasai pembelian dengan mengendalikan harga dan kuantitas pembelian. (Contoh: Indikasi awal terlihat dari kontrol pabrik rokok atas gudang-gudang pembelian yang cenderung merugikan petani tembakau).

11) Perjanjian integrasi vertikal penguasaan produksi berangkai/ sejenis. (Contoh: impor gandum, pengolahan gandum, dst).

12) Perjanjian tertutup hanya menerima dan memasok (Exclusive kepada pihak tertentu. dealing).

13) Perjanjian dengan pihak luar negeri yang mengakibatkan praktik monopoli.

\section{Perjanjian Karya Pengusahaan Pertambangan Batubara (PKP2B)}

Indonesia sebagai negara kepulauan sangat kaya dengan sumber daya alam, diantaranya batubara. Batubara merupakan bentukan sedimen senyawa organik alami dari sisa tanaman alam dengan tingkat berbeda dari lignite.

Batubara digunakan untuk pembangkit tenaga listrik, industri pabrik dan sebagainya., Batubara sebagai energi alternatif memiliki nilai ekonomi strategis untuk kehidupan dan kepentingan rakyat Indonesia yang berpotensi meningkatkan pendapatan negara.

Pertambangan di Indonesia semakin prospektif dimana Indonesia sebagai negara yang memiliki sumber daya alam berlimpah menarik minat pengusaha asing untuk berinvestasi di Indonesia. Hal ini dilakukan dalam bentuk kerjasama yang ditawarkan oleh pihak asing dalam bentuk kontrak / perjanjian.

Dalam perjanjian perlu dipertimbangkan beberapa prinsip, 
yaitu prinsip keseimbangan, prinsipprinsip kebebasan kontrak dan prinsip syarat perbandingan hak dan kewajiban dari masing-masing pihak, serta beberapa hal yang terkandung dalam BW pasal 1320. Hal berikutnya yang perlu disampaikan adalah potensi pelanggaran kontrak yang dilakukan oleh salah satu pihak yang tidak menjalankan kewajiban sesuai kontrak.

Peraturan perundang-undangan dalam pertambangan sumber daya mineral dan batubara yang saat ini berlaku di Indonesia adalah UU No. 4 Tahun 2009 tentang Pertambangan Mineral dan Batubara atau dikenal dengan UU Minerba. Dalam kenyataannya tidak semua hal yang terkait dengan usaha pertambangan sumber daya mineral dan batubara sesuai dengan UU Minerba dengan masih berlakunya KK (Kontrak Karya) bagi Perusahaan Pertambangan Mineral dan PKP2B (Perjanjian Karya Pengusahaan Pertambangan Batubara) bagi Perusahaan Pertambangan Batubara dalam melaksanakan kegiatan pertambangan mereka, padahal UU No. 11 Tahun 1967 tentang Ketentuan-Ketentuan Pokok Pertambangan yang melandasi isi dari ketentuan yang termaktub dalam Kontrak Karya dan PKP2B dinyatakan tidak berlaku lagi.

Dalam penulisan ini, pembahasan dibatasi hanya untuk pertambangan batubara saja, sehingga ketentuan dan peraturan yang dipergunakan adalah ketentuan tentang Perjanjian Karya Pengusahaan Pertambangan Batubara (PKP2B).

\section{Penerapan Hukum Perjanjian Secara Umum Serta Penerapannya Dalam Perjanjian Karya Pengusahaan Pertambangan Batubara (PKP2B)}

a. Penerapan Hukum Perjanjian Secara Umum

Perjanjian yang berlaku umum di masyarakat saat ini adalah perjanjian obligatoir yang bersifat konsensuil, artinya perjanjian dianggap sah apabila ada kata sepakat antara kedua belah pihak yang mengadakan perjanjian tersebut.

1) Ditinjau Dari Hukum Privat (http://lista.staff.gunadarma.ac.id)

Suatu perjanjian adalah suatu perbuatan dengan mana satu orang atau lebih mengikatkan dirinya terhadap satu orang lain/lebih (Pasal 1313 BW). Pengertian perjanjian ini mengandung unsur:

a) Penggunaan kata "Perbuatan" pada perumusan tentang Perjanjian ini lebih tepat jika diganti dengan kata perbuatan hukum atau tindakan hukum, karena perbuatan tersebut membawa akibat hukum bagi para pihak yang memperjanjikan;

b) Satu orang atau lebih terhadap satu orang lain atau lebih, Untuk adanya suatu perjanjian, paling sedikit harus ada dua pihak yang saling berhadapan dan saling memberikan pernyataan yang tepat satu sama lain. Pihak tersebut adalah orang atau badan hukum.

c) Mengikatkan dirinya, Di dalam perjanjian terdapat unsur janji yang diberikan oleh pihak yang satu kepada pihak yang lain. 
Dalam perjanjian ini orang terikat kepada akibat hukum yang muncul karena kehendaknya sendiri.

Menurut pasal 1331 KUHPerdata, semua perjanjian yang dibuat secara sah berlaku sebagai undang-undang bagi mereka yang membuatnya. Apabila perjanjian yang dilakukan obyek/perihalnya tidak ada atau tidak didasari pada itikad yang baik, maka dengan sendirinya perjanjian tersebut batal demi hukum. Dalam kondisi ini perjanjian dianggap tidak pernah ada, dan lebih lanjut para pihak tidak memiliki dasar penuntutan di depan hakim. Sedangkan untuk perjanjian yang tidak memenuhi unsur subyektif seperti perjanjian dibawah paksaan dan atau terdapat pihak dibawah umur atau dibawah pengawasan, maka perjanjian ini dapat dimintakan pembatalan (kepada hakim) oleh pihak yang tidak mampu termasuk wali atau pengampunya. Dengan kata lain, apabila tidak dimintakan pembatalan maka perjanjian tersebut tetap mengikat para pihak.

Prinsipnya, hukum perjanjian menganut asas konsensualisme artinya bahwa perikatan timbul sejak terjadi kesepakatan antara para pihak sehingga apabila salah satu pihak tidak melaksanakan perjanjian atau wanprestasi, maka akan timbul 4 akibat yang dapat terjadi, yaitu:
a) Membayar kerugian yang diderita oleh pihak lain berupa ganti-rugi
b) Dilakukan
pembatalan
c) Peralihan resiko

d) Membayar biaya perkara jika sampai berperkara dimuka hakim

Memperoleh pengakuan wanprestasi tidaklah mudah, sehingga apabila yang bersangkutan menyangkal telah dilakukannya wanprestasi, dapat dilakukan pembuktian di depan pengadilan dimana sebelumnya dikeluarkan surat peringatan atau teguran atau somasi.

Pedoman penting penafsiran suatu perjanjian :

a) Jika kata-kata dalam perjanjian jelas, maka tidak diperkenankan menyimpangkan dengan penafsiran.

b) Jika mengandung banyak penafsiran, maka harus diselidiki maksud perjanjian oleh kedua pihak, dari pada memegang teguh arti kata-kata.

c) Jika janji berisi dua pengertian, maka harus dipilih pengertian yang memungkinkan janji dilaksanakan

d) Jika kata-kata mengandung dua pengertian, maka dipilih pengertian yang selaras dengan sifat perjanjian

e) Apa yang meragukan, harus ditafsirkan menurut apa yang menjadi kebiasaan.

f) Tiap janji harus ditafsirkan dalam rangka perjanjian seluruhnya.

Pasal 1338 ayat KUHPerdata, menyatakan bahwa semua kontrak (perjanjian) yang dibuat secara sah berlaku sebagai undang-undang bagi mereka yang membuatnya. Dari Pasal 1338 ayat (1) KUHPerdata ini dapat disimpulkan adanya asas kebebasan 
berkontrak, akan tetapi kebebasan ini dibatasi oleh hukum yang sifatnya memaksa, sehingga para pihak yang membuat perjanjian harus menaati hukum yang sifatnya memaksa. Suatu perjanjian tidak dapat ditarik kembali selain dengan sepakat kedua belah pihak, atau karena alasan-alasan yang oleh undang-undang dinyatakan cukup untuk itu.

Perjanjian tidak hanya mengikat untuk hal-hal yang dengan tegas dinyatakan didalamnya, tetapi juga untuk segala sesuatu yang menurut sifat perjanjian, diharuskan oleh kepatutan, kebiasaan atau undangundang.

Suatu perjanjian dikatakan perjanjian berakhir bila:

a) ditentukan oleh para pihak berlaku untuk waktu tertentu;

b) undang-undang

menentukan batas berlakunya perjanjian;

c) para pihak atau undangundang menentukan bahwa dengan terjadinya peristiwa tertentu maka persetujuan akan hapus;

Peristiwa tertentu yang dimaksud adalah keadaan memaksa (overmacht) yang diatur dalam Pasal 1244 dan 1245 KUH Perdata. Keadaan memaksa adalah suatu keadaan dimana debitur tidak dapat melakukan prestasinya kepada kreditur yang disebabkan adanya kejadian yang berada di luar kekuasaannya, misalnya karena adanya gempa bumi, banjir, lahar dan lain-lain. Keadaan memaksa dapat dibagi menjadi dua macam yaitu keadaan memaksa absolut adalah suatu keadaan di mana debitur sama sekali tidak dapat memenuhi perutangannya kepada kreditur, oleh karena adanya gempa bumi, banjir bandang, dan adanya lahar (force majeur).

Akibat keadaan memaksa absolut (force majeur) :

a) debitur tidak perlu membayar ganti rugi (Pasal $1244 \mathrm{KUH}$ Perdata);

b) kreditur tidak berhak atas pemenuhan prestasi, tetapi sekaligus demi hukum bebas dari kewajibannya untuk menyerahkan kontra prestasi, kecuali untuk yang disebut dalam Pasal 1460 KUH Perdata.

c) keadaan memaksa yang relatif adalah suatu keadaan yang menyebabkan debitur masih mungkin untuk melaksanakan prestasinya, tetapi pelaksanaan prestasi itu harus dilakukan dengan memberikan korban besar yang tidak seimbang atau menggunakan kekuatan jiwa yang di luar kemampuan manusia atau kemungkinan tertimpa bahaya kerugian yang sangat besar. Keadaan memaksa ini tidak mengakibatkan beban resiko apapun, hanya masalah waktu pelaksanaan hak dan kewajiban kreditur dan debitur.

d) pernyataan menghentikan persetujuan (opzegging) yang dapat dilakukan oleh kedua belah pihak atau oleh salah satu pihak pada perjanjian yang bersifat sementara misalnya perjanjian kerja;

e) putusan hakim;

f) tujuan perjanjian telah tercapai;

g) dengan persetujuan para pihak (herroeping).

\section{Ditinjau Dari Hukum Publik}


Dalam Hukum Publik, perjanjian menunjuk kepada Perjanjian Internasional dan memainkan peranan yang sangat penting dalam mengatur kehidupan dan pergaulan antar negara. Perjanjian Internasional hakekatnya merupakan sumber hukum internasional yang utama untuk mengatur kegiatan negaranegara atau subjek hukum internasional lainnya.

Konvensi Wina pada tahun 1969 mendefinisikan perjanjian internasional (treaty) adalah suatu persetujuan yang dibuat antar negara dalam bentuk tertulis, dan diatur oleh hukum internasional, apakah dalam instrumen tunggal atau dua atau lebih instrumen yang berkaitan dan apapun nama yang diberikan kepadanya.

Pengertian tersebut di atas mengandung unsur :

a) Adanya subjek hukum internasional, yaitu negara, organisasi internasional dan gerakan-gerakan pembebasan. Pengakuan negara sebagai sebagai subjek hukum internasional yang mempunyai kapasitas penuh untuk membuat perjanjian-perjanjian internasional tercantum dalam Pasal 6 Konvensi Wina. Organisasi internasional juga diakui sebagai pihak yang membuat perjanjian dengan persyaratan kehendak membuat perjanjian berasal dari negara-negara anggota dan perjanjian internasional yang dibuat merupakan bidang kewenangan organisasi internasional tersebut. b) Rezim hukum internasional, perjanjian internasional harus tunduk pada hukum internasional dan tidak boleh tunduk pada suatu hukum nasional tertentu. Walaupun perjanjian itu dibuat oleh negara atau organisasi internasional namun apabila telah tunduk pada suatu hukum nasional tertentu yang dipilih, perjanjian tersebut bukanlah perjanjian internasional.

Dalam perjanjian yang ditinjau dari hukum publik ini, kata sepakat hanya menunjukkan kesaksian naskah perjanjian, bukan keabsahan perjanjian. Dan setelah perjanjian itu sah, tidak serta merta mengikat para pihak apabila para pihak belum melakukan ratifikasi.

Tahapan pembuatan perjanjian ini meliputi :

a) Perundingan dimana negara mengirimkan utusannya ke suatu konferensi bilateral maupun multilateral.

b) Penerimaan naskah perjanjian (adoption of the text) adalah penerimaan isi naskah perjanjian oleh peserta konferensi yang ditentukan dengan persetujuan dari semua peserta melalui pemungutan suara.

c) Kesaksian naskah perjanjian (authentication of the text), merupakan suatu tindakan formal yang menyatakan bahwa naskah perjanjian tersebut telah diterima konferensi.

d) Persetujuan mengikatkan diri (consent to the bound), diberikan dalam bermacam cara tergantung pada permufakatan 
para pihak pada waktumengadakan perjanjian, dimana cara untuk menyatakan persetujuan adalah sebagai berikut:

oPenandatanganan, pasal 12 Konvensi Wina menyatakan:

- persetujuan negara untuk diikat suatu perjanjian dapat dinyatakan dalam bentuk tandatangan wakil negara tersebut;

- bila perjanjian itu sendiri yang menyatakannya;

- bila terbukti bahwa negaranegara yang ikut berunding menyetujui demikian;

- bila full powers wakil-wakil negara menyebutkan demikian atau dinyatakan dengan jelas pada waktu perundingan.

Pengesahan, melalui ratifikasi dimana perjanjian tersebut disahkan oleh badan yang berwenang di negara anggota.

Pasal 26 Konvensi Wina menyatakan bahwa tiap-tiap perjanjian yang berlaku mengikat negara-negara pihak dan harus dilaksanakan dengan itikad baik atau in good faith. Pelaksanaan perjanjian itu dilakukan oleh organ-organ negara yang harus mengambil tindakan yang diperlukan untuk menjamin pelaksanaannya. Daya ikat perjanjian didasarkan pada prinsip pacta sunt servanda.

Berbeda dengan perjanjian dalam lapangan hukum privat yang tidak boleh menimbulkan hak dan kewajiban bagi pihak ketiga, perjanjian internasional dapat menimbulkan akibat bagi pihak ketiga atas persetujuan mereka, dapat memberikan hak kepada negara-negara ketiga atau mempunyai akibat pada negara ketiga tanpa persetujuan negara tersebut (contoh : Pasal 2 (6) Piagam PBB yang menyatakan bahwa negaranegara bukan anggota PBB harus bertindak sesuai dengan asas PBB sejauh mungkin bila dianggap perlu untuk perdamaian dan keamanan internasional). Pasal 35 Konvensi Wina mengatur bahwa perjanjian internasional dapat menimbulkan akibat bagi pihak ketiga berupa kewajiban atas persetujuan mereka dimana persetujuan tersebut diwujudkan dalam bentuk tertulis. Perjanjian ditinjau dalam hukum publik dikatakan berakhir apabila :

a) sesuai dengan ketentuan perjanjian itu sendiri;

b) atas persetujuan kemudian yang dituangkan dalam perjanjian tersendiri;

c) akibat peristiwa-peristiwa tertentu yaitu tidak dilaksanakannya perjanjian, perubahan kendaraan yang bersifat mendasar pada negara anggota, timbulnya norma hukum internasional yang baru yaitu perang.

\section{Penerapan hukum perjanjian dalam perspektif Perjanjian Karya Pengusahaan Pertambangan Batubara (PKP2B)}

Sebagaimana

diketahui Perjanjian Karya Pengusahaan Pertambangan Batubara (PKP2B) adalah Perjanjian antara Pemerintah Republik Indonesia dan Perusahaan Swasta Asing berdasar UU No. 1 Tahun 1967 tentang Investasi Asing dan UU No. 11 Tahun 1967 tentang Ketentuan Dasar dan Pertambangan 
Umum, sesuai Pasal 1 Keputusan Menteri Pertambangan dan Energi No. 1409.K/201/M.PE/1996 tentang Perjanjian Karya Pengusahaan Pertambangan Batubara (PKP2B).

Perjanjian ini disebut juga perjanjian karya, sebagaimana terdapat dalam pasal 10 ayat (2) dan ayat (3) UU No. 11 Tahun 1967. Namun konstruksi yang dipergunakan dalam ketentuan ini tidak hanya perjanjian dalam pertambangan batubara semata, tetapi juga pertambangan emas, tembaga, perak dan lain-lain.

Hukum perjanjian ini diterapkan untuk mengakomodir Keppres No. 49 Tahun 1981, utamanya pasal 1 tentang KetentuanKetentuan Pokok Perjanjian Kerjasama Pengusahaan Tambang Batubara antara perusahaan Tambang Batubara dan Konstraktor swasta, istilah yang dipergunakan adalah perjanjian kerjasama, yaitu perjanjian antara perusahaan negara tambang batubara sebagai pemegang kuasa pertambangan dan pihak swasta sebagai kontraktor untuk pengusahaan tambang batubara untuk jangka waktu tiga puluh tahun berdasarkan ketentuan-ketentuan tersebut dalam Keppres ini.

Perjanjian kerjasama ini diadakan antara:

a. Perusahaan Negara tambang batubara dengan kontraktor

b. Obyek pengusahaannya adalah batubara

$$
\text { c. Jangka waktunya }
$$

adalah tiga puluh tahun

d. Pelaksanaan perjanjian kerjasama ini didasarkan pada Keppres No. 49 Tahun 1981
Pengertian perjanjian karya pengusahaan pertambangan batubara dalam pasal 1 Keppres No. 75 Tahun 1996, yaitu: 'perjanjian antara pemerintah dan perusahaan kontraktor swasta untuk melaksanakan pengusahaan pertambangan bahan galian batubara".

Definisi lain tentang perjanjian karya pengusahaan pertambangan batubara dapat dilihat dalam pasal 1 Keputusan Menteri Pertambangan dan Energi No. 1409.K/201/M.PE/1996 tentang Tata Cara Pengajuan Pemrosesan Pemberian Kuasa Pertambangan, Izin Prinsip, Kontrak Karya dan Perjanjian Karya Pengusahaan Pertambangan Batubara. Dalam ketentuan itu, disebutkan bahwa perjanjian karya pengusahaan pertambangan batubara (PKP2B) adalah: ' suatu perjanjian antara Pemerintah Republik Indonesia dengan perusahaan swasta asing atau patungan antara asing dengan nasional (dalam rangka PMA) untuk pengusahaan batubara dengan berpedoman kepada UU No. 1 Tahun 1967 tentang Penanaman Modal Asing serta UU No. 11 Tahun 1967 tentang Ketentuan-ketentuan Pokok Pertambangan Umum".

Unsur-unsur yang terdapat dalam Pasal 1 Keppres No. 75 Tahun 1996:

a. Para pihak dalam perjanjian ini adalah pemerintah dan perusahaan kontraktor swasta

b. Obyeknya adalah pengusahaan pertambangan bahan galian batubara.

Unsur-unsur yang terdapat dalam pasal 1 Keputusan Menteri 
Pertambangan dan Energi No. 1409.K/201/M.PE/1996 :

a. Adanya perjanjian

b. Subyek hukumnya adalah Pemerintah Republik Indonesia dengan perusahaan swasta asing atau patungan antara asing dengan nasional (dalam rangka PMA).

c. Obyeknya adalah untuk pengusahaan batubara.

d. Pedoman yang digunakan dalam perjanjian karya adalah UU No. 1 Tahun 1967 tentang Penanaman Modal Asing serta UU No. 11 Tahun 1967 tentang Ketentuan-ketentuan Pokok Pertambangan Umum.

Dalam Pasal 1 Keppres No. 75 Tahun 1996, tidak dijelaskan secara rinci tentang perusahaan kontraktor swasta yang dapat melakukan pengusahaan batubara. Sementara dalam pasal 1 Keputusan Menteri Pertambangan dan Energi No. 1409.K/201/M.PE/1996, perusahaan kontraktor swasta yang dapat melakukan pengusahaan batubara tidak hanya swasta nasional, tapi juga swasta asing dan atau gabungan antara perusahaan swasta nasional dengan swasta asing. Persamaan dari kedua unsur perjanjian karya pengusahaan pertambangan batubara adalah memiliki obyek yang sama, yaitu pengusahaan batubara.

Prinsip-prinsip dalam perjanjian karya pengusahaan pertambangan batubara seperti terdapat dalam Pasal 2 dan 3 Keppres No. 75 Tahun 1996 adalah :

a. Perusahaan kontraktor swasta bertanggung jawab atas pengelolaan pengusahaan penambangan batubara yang dilaksanakan berdasarkan perjanjian.

b. Perusahaan kontraktor swasta menanggung semua resiko dan semua biaya berdasarkan perjanjian dalam melaksanakan perusahaan pertambangan batubara.

Perjanjian Karya Pengusahaan Pertambangan Batubara (PKP2B) diperkenalkan pertama kalinya di Indonesia pada tahun 1996, sesuai dengan Keputusan Presiden No. 75 Tahun 1996 tentang Ketentuan Dasar Perjanjian Kerja dari Tambang Batubara dan Keputusan Menteri Pertambangan dan Energi No. No. 1409.K/ 201/M. PE/Tahun 1996 tentang Perjanjian Karya Pengusahaan Pertambangan Batubara (PKP2B).

Perjanjian Karya Pengusahaan Pertambangan Batubara (PKP2B) merujuk kepada Pasal 1338 BW yang dikenal sebagai kebebasan persetujuan prinsip/kontrak. Ditegaskan bahwa para pihak telah setuju untuk mengikat satu sama lain dalam perjanjian itu, dengan demikian kesepakatan itu menjadi hukum dan mengikat bagi kedua belah pihak yang penandatanganan ini, tetapi terbatas oleh Pasal 1320 BW. Dengan demikian persyaratan legalisasi Perjanjian Karya Pengusahaan Pertambangan Batubara (PKP2B) adalah sama dengan persetujuan dan sesuai ketentuan dalam Pasal 1320 BW.

Sebagaimana kita ketahui dari pandangan hukum seyogyanya semua kegiatan yang berkaitan dengan pertambangan mineral dan batubara haruslah sesuai dengan UUD 1945 Pasal 33 ayat (2) dan (3) dan UU No. 
4 Tahun 2009. Apabila tidak sesuai maka kegiatan tersebut bertentangan dengan hukum kecuali memang sudah diatur secara jelas dalam ketentuan UU yang merupakan pasalpasal pengecualian.

Kontrak Karya dan PKP2B diatur dalam UU No. 4 Tahun 2009 pada Bab XXV tentang Ketentuan Peralihan Pasal 169 yang berbunyi sebagai berikut :

a. Kontrak Karya dan perjanjian karya pengusahaan pertambangan batubara yang telah ada sebelum berlakunya UU ini tetap diberlakukan sampai jangka waktu berakhirnya kontrak/ perjanjian.

b. Ketentuan yang tercantum dalam pasal kontrak karya dan perjanjian karya pengusahaan pertambangan batubara sebagaimana dimaksud pada huruf a disesuaikan selambatlambatnya 1 (satu) tahun sejak UU ini diundangkan kecuali mengenai penerimaan negara.

Penafsiran dari ketentuan di atas adalah UU Minerba ini menjamin dari segi jangka waktu bahwa kontrak/ perjanjian yang sudah disepakati tidak akan sewaktu-waktu diputus oleh Pemerintah, sehingga pelaku usaha bisa tenang melanjutkan usahanya. Hal ini merupakan penghormatan pemerintah terhadap kontrak yang telah dibuat dahulu oleh pemerintah baik dengan Perusahaan Pertambangan Mineral atau dengan Perusahaan Pertambangan Batubara. Namun secara terang diatur bahwa semua pasal yang terkandung dalam kontrak karya dan perjanjian karya pengusahaan pertambangan harus disesuaikan dengan UU No. 4 Tahun 2009 paling lambat 1 tahun sejak UU Minerba berlaku.

\section{Simpulan}

Berdasarkan hasil pembahasan diatas, maka dapat disimpulkan beberapa hal sebagai berikut:

1. Pada dasarnya tidak akan ada kesepakatan yang mengikat suatu pihak jika tidak ada perjanjian yang disepakati oleh masing-masing pihak, sehingga perikatan merupakan konsekuensi logis dari pada perjanjian.

2. Sejatinya hukum perjanjian, baik hukum privat maupun publik akan sah dan memiliki kekuatan mengikat bagi para pihak yang memperjanjikan jika sudah memenuhi syarat-syarat yang ditentukan untuk dinyatakan sah, termasuk dengan pihak ketiga.

3. Subjek perjanjian dalam hukum privat adalah individu atau badan hukum, sementara subjek perjanjian dalam hukum publik adalah subjek hukum internasional yaitu negara, organisasi internasional dan gerakan-gerakan pembebasan.

4. Dalam kitab Undang undang Hukum Perdata (KUHPerdata) Pasal 1331 dinyatakan secara jelas bahwa semua perjanjian yang dibuat secara sah berlaku sebagai undang undang bagi mereka yang membuatnya.

5. Perjanjian Karya Pengusahaan Pertambangan Batubara (PKP2B) ditinjau dari hukum perjanjian, dapat disampaikan 
bahwa perjanjian ini menurut UU No. 4 Tahun 2009 dianggap masih berlaku hingga berakhir periode perjanjian.

6. Pengaturan hak dan kewajiban dalam Perjanjian Karya Pengusahaan Pertambangan Batubara (PKP2B) dengan Pemerintah Indonesia sebenarnya telah sesuai dengan ketentuan pasal 1320 KUHPerdata tentang sahnya perjanjian yakni sepakat mereka mengikat diri, cakap untuk membuat perjanjian, mengenai hal tertentu, suatu sebab yang halal, serta telah sesuai dengan asas kebebasan berkontrak, asas kesimbangan, dan asas proporsionalitas.

7. Ketentuan-ketentuan yang tercantum dalam perjanjian karya pengusahaan pertambangan batubara yang telah diupayakan untuk disesuaikan dengan UU No. 4 Tahun 2009, dalam kenyataannya masih belum dilaksanakan secara optimal oleh pemerintah sebagai pihak yang mewakili Negara dan Rakyat Indonesia. Padahal UU Minerba sudah berlaku 4 tahun lebih. Amanatnyapun harus sudah dilakukan setahun setelah UU No. 4 Tahun 2009 atau tanggal 12 Januari 2010. Untuk itu diharapkan pemerintah segera melaksanakan ketentuan UU dengan cara menertibkan ketentuan-ketentuan yang ada dalam Perjanjian Karya Pengusahaan Pertambangan Batubara.

\section{Daftar Pustaka}

\section{Sumber Buku:}

Atiyah, Patrick Selim, 1988. The Rise and Fall of Freedom of Contract. New York: Oxford University Press.

Black, Henry Campbell. 1990. Black's Law Dictionary. Sixth Edition, St Paul, Minn West Publising Co.

Darus, Badrulzaman Mariam, 1996. Kitab Undang-undang Hukum Perdata Buku III Tentang Hukum Perikatan Dengan Penjelasan. Edisi II. Cet. I. Bandung: Alumni.

Dawarja, Agustinus, 2007. PERJANJIAN - Pengertian Pokok dan Teknik Perancangannya.

Downes, T. Antony, 1997. Textbook on Contract. Fifth Edition. Published by Blackstone Press Ltd.

Eisenberg, Melvin Aron, 1991. The Nature of The Comon Law. Harvard University Press, Massachusetts.

Fred R, David, 1997. Strategic Manegement. Prentice-Hall International, Inc. New Jersey.

Friedmann, W, 1960. Legal Theory. Forth Edition. London: Stevens \& Sons Limited.

Harahap, M. Yahya, 1986. Segi-Segi Hukum Perjanjian. Cetakan Kedua. Bandung: Alumni.

Ichsan, A, 1994. Hukum Perdata IB, dalam R. Setiawan, PokokPokok Hukum Perikatan. Cetakan Kelima. Bandung: Bina Cipta. 
Kendrick, Ewan Mc, 2003. Contract Law. Palgrave Macmillan. Fifth Edition. New York.

Meliala, Qirom Syamsudin, 1985. Pokok-pokok Hukum Perjanjian Beserta Perkembangannya . Yogyakarta: Liberty.

Muhammad, Abdulkadir, 2000. Hukum Perdata Indonesia. Bandung: PT. Citra Aditya Bakti, Bandung.

Pangaribuan simanjuntak, SH., Prof Emmy. 1994. Perusahaan Kelompok. Yogyakarta: Seksi Hukum Dagang Fakultas Hukum Universitas Gadjah Mada

Pramono, Nindyo. Hukum Komersil, (Jakarta: Pusat Penerbitan UT, 2003), Cet. 1

Patrik, Purwahid, 1994. Dasar-dasar hukum Perikatan. Bandung: Mandar Maju.

Prawirohamidjojo, Soetojo dkk, 1978. Hukum Perikatan. Surabaya: Bina Ilmu.

Prodjodikoro, Wirjono, 1986. AsasAsas Hukum Perjanjian. Bandung: PT. Bale.

Prodjodikoro and R Wirjono, 1989. Azas-azas Hukum Perjanjian. Cetakan ke-Sebelas. Bandung: PT. Bale.

Pitlo, 1985. Materi Kegiatan Praktikum Penyusunan Kontrak Nasional, Laboratorium Fakultas Hukum, Bandung: Universitas Padjadjaran.

Santoso, Djohari dan Ali Achmad, 1989. Hukum Perjanjian Indonesia. Yogyakarta: Perpustakaan FH UII.
Satrio, 2001. Hukum PerikatanPerikatan Yang Lahir Dari Perjanjian Buku I. Bandung : PT. Citra Aditya Bakti.

,1995. Hukum Perikatan Perikatan Yang Lahir Dari Perjanjian Buku II. Bandung: PT. Citra Aditya Bakti.

,1992. Hukum Perjanjian (Perjanjian Pada Umumnya). Bandung: PT. Citra Aditya Bakti.

Setiawan, 1994. Pokok-Pokok Hukum Perikatan, Cetakan Kelima. Bandung: Bina Cipta.

Suryodiningrat, 1985. Azas-azas Hukum Perikatan. Bandung: Tarsito.

Subekti dan Tjitrosudibio R, 1992. KUHPER. Jakarta: PT. Pradnya Paramita. 1996. Kitab Undang-Undang Hukum Perdata. Jakarta: Pradnya Paramita.

Subekti, 1992. Aspek-Aspek Hukum Perikatan Nasional, Cet. ke-4. Bandung: PT. Citra Aditya Bakti.

1985. Aneka Perjanjian. Cetakan Ketujuh. Bandung: Alumni.

1995. Aneka Perjanjian. Bandung: PT. Citra Aditya Bakti.

. Hukum Perjanjian. Cetakan ke XI. Jakarta: Intermasa. Hukum Perjanjian. Cetakan ke XII. Jakarta: Intermasa. 1996. Hukum Perjanjian. Cetakan ke XVI. Jakarta: Intermasa. 
1992. Pokok-pokok Hukum Perdata. Jakarta: PT. Intermasa.

Suharnoko. Hukum Perjanjian - Teori dan Analisa Kasus.

Suryodiningrat, 1982. Perikatan perikatan Bersumber Perjanjian. Bandung: Tarsito

Sofran, Sri Soedewi Masjhoen, 1987. Pengantar Hukum Perdata Internasional Indonesia. Bandung: Bina Cipta.

Tungadi, Tahir, 1979. Hukum Perjanjian. Ujung Pandang: Universitas Hasanudin.

Wijaya, Gunawan dan Muljadi Kartini, 2004. Jual Beli. Jakarta: PT Raja Grafindo Persada.

Wild, Susan Ellis, 2006. Webster's New World Law Dictionary. Canada: Wiley Publishing.

\section{Sumber Jurnal \& Paper:}

Marzuki, Peter Mahmud, 2003. "Batas-batas Kebebasan Berkontrak", Artikel dalam Jurnal Yuridika, Volume 18 No. 3.

Susanto, Sri Nur Hari. Penguasaan Daerah Atas Bahan Galian/ Pertambangan Dalam Perspektif Otonomi Daerah, Disampaikan pada Seminar Nasional Aspek Hukum Penguasaan Daerah Atas Bahan Galian, di Fakultas Hukum Undip pada 2 Desember 2009.

\section{Sumber Peraturan Perundangan:}

Undang - Undang Dasar 1945 Pasal 33 Ayat (3).

Undang - Undang Dasar 1945, Tambahan Lembaran Negara, Lembaran Negara No. 14 Tahun 2006.
Undang - Undang No. 5 Tahun 1960 Tentang Peraturan Dasar Pokok - Pokok Agraria.

Undang - Undang No. 11 Tahun 1967 Tentang Ketentuan - ketentuan Pokok Pertambangan.

Undang - Undang No. 40 Tahun 2007 Tentang Perseroan Terbatas.

Undang - Undang No. 4 Tahun 2009 Tentang Pertambangan Mineral dan Batubara .

Peraturan Pemerintah No. 32 Tahun 1969 Tentang Pelaksanaan Undang - undang No. 11 Tahun 1967 Tentang Ketentuan ketentuan Pokok Pertambangan.

\section{Sumber Internet:}

http://www.hukumonline.com/berit a/baca/hol21259/bumn-kawalpenyusunan-pp pelaksana-uuminerba.

http://hukumonline.com/berita/bac a/hol21000/menteri-esdmpemerintah-adalah pengaturbukan-pemain.

http://www.hukumonline.com/pusat data/detail/cl6802/node/lt4a0 a533e31979/ transfer-pricing.

http://www.lexregis.com/?menu=leg al_article\&id_la $=11$.

http://www.scribd.com/doc/512559 35/bab-I-Definisi-dan-TujuanHukum.

http://sikumendes84.wordpress.com

http://mitrahukum.org/devel/wpcon tent/uploads/2012/09/teori_h ukum_soetandyo.

http://herikurniawan19.wordpress.c om/2012/04/06/hukumperjanjian.

http://budikelanasosrosubroto.blogs pot.com/2012/06/hukum- 
perikatan-perjanjian - dandagang.html.

http://www.jurnalhukum.com/penge rtian-perikatan.

http://hanim.blog.unissula.ac.id/201

1/10/07/wanprestasi-

overmacht-dan hapusnya

perjanjian-pengabdian-

masyarakat.

http://www.legalakses.com/asasasas-perjanjian.

http://www.jurnalhukum.com/jenisjenis-perjanjian.

http://lista.staff.gunadarma.ac.id/Do wnloads/files/19365/Hukum+

Perjanjian.

ejurnal.ung.ac.id/index.php/JPI/articl

e. 